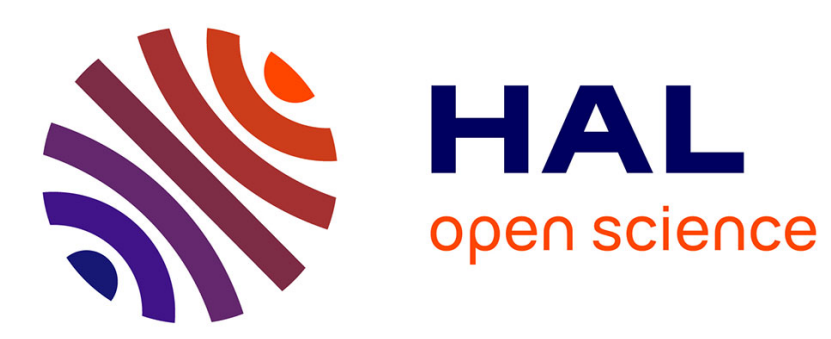

\title{
Minimum Age Regulation and Child Labor: New Evidence from Brazil
}

Olivier Bargain, Delphine Boutin

\section{To cite this version:}

Olivier Bargain, Delphine Boutin. Minimum Age Regulation and Child Labor: New Evidence from Brazil. 2017. hal-01629988

\section{HAL Id: hal-01629988 \\ https://hal.science/hal-01629988}

Preprint submitted on 7 Nov 2017

HAL is a multi-disciplinary open access archive for the deposit and dissemination of scientific research documents, whether they are published or not. The documents may come from teaching and research institutions in France or abroad, or from public or private research centers.
L'archive ouverte pluridisciplinaire HAL, est destinée au dépôt et à la diffusion de documents scientifiques de niveau recherche, publiés ou non, émanant des établissements d'enseignement et de recherche français ou étrangers, des laboratoires publics ou privés. 


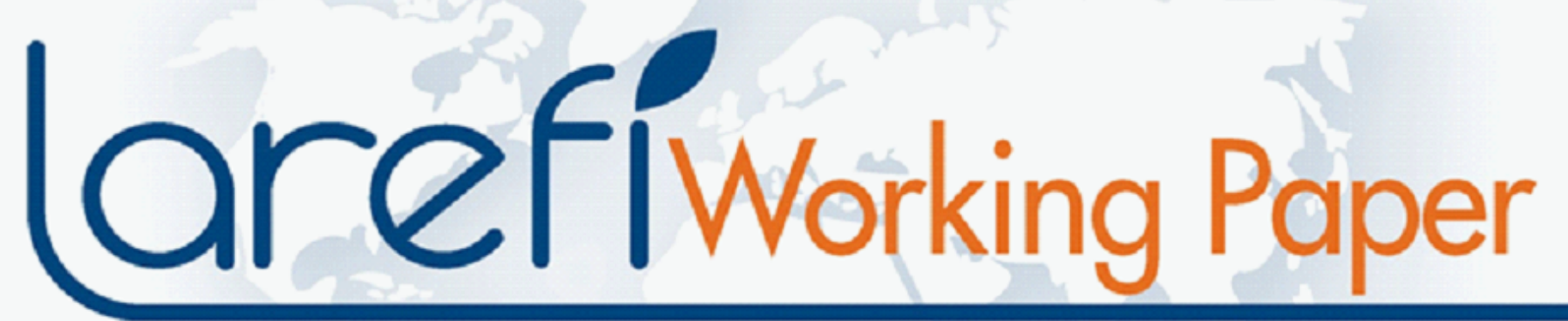

Laboratoire d'Analyse et de Recherche en Économie et Finance Internationales

\title{
Minimum Age Regulation and Child Labor: New Evidence from Brazil
}

Olivier Bargain and Delphine Boutin

\section{LAREFI Working Paper N²017-02}

\author{
https://larefi.u-bordeaux.fr/
}




\section{AUTHORS}

Olivier Bargain and Delphine Boutin *

\section{NOTICES}

LAREFI Working Papers contain preliminary material and research results. They have been peer reviewed. They are circulated in order to stimulate discussion and critical comment; any opinions expressed are only those of the author(s).

Copyright LAREFI. All rights reserved. Sections of this material may be reproduced for personal and not-forprofit use without the express written permission of but with acknowledgment to LAREFI.

To reproduce the material contained herein for profit or commercial use requires express written permission. To obtain permission, contact LAREFI at cyril.mesmer@u-bordeaux.fr.

*Acknowledgement: Bargain is affi liated with Bordeaux University, the 'Institut Universitaire de France' and IZA; Boutin with Université d' Auvergne,CERDI and IZA. Corresponding author: Olivier Bargain, LAREFI, rue Leon Duguit, 33608 Pessac, France, olivier.bargain@u-bordeaux.fr 


\title{
Minimum Age Regulation and Child Labor: New Evidence from Brazil
}

\author{
Olivier Bargain and Delphine Boutin
}

November 6, 2017

\begin{abstract}
We suggest new evidence on minimum age regulations using a natural experiment. In 1998, a constitutional reform has changed the minimum working age from 14 to 16 in Brazil. The reform was the legislative counterpart of a broad set of measures taken by a government strongly committed to fighting child labor. We document the fact that enforcement and compliance may have been heterogeneous across regions and job types. The setting allows improving upon past approaches based on the comparison of employment rates of children below and above the minimum age. Precisely, we observe 14-year old children the year after the reform and exploit discontinuous treatment depending on their birthdate (only those who turned 14 after mid-December 1998 are banned). Regression discontinuity and difference-in-discontinuity designs show no effect of the ban overall, nor a reallocation towards less visible activities, or a substitution of labor within families. Importantly, however, we find a significant drop in child labor among those with highest chances of compliance, namely children in visible activities and in regions characterized with an above-average intensity of labor inspections. We provide power calculation and extensive sensitivity checks.
\end{abstract}

Key Words : child labor, ban, minimum working age, Brazil, regression discontinuity, difference in discontinuity.

JEL Classification : J08, J22, J23, J88. 


\section{Introduction}

Child labor bans in the form of minimum legal age of employment exist in most countries in the world. In principle, these regulations could decrease child labor if applied uniformly across different types of activities. In practice, they may lead to a reallocation of child labor towards unregulated sectors (like family businesses) where they are not applied or where detection is hard to enforce. Overall, there is little evidence that minimum age of employment regulations have any effect at all, and in particular that they are influencing child engagement in paid employment (Edmonds and Shrestha, 2012). There are two main reasons for this observation. First, it seems that minimum age regulations are not enforced in general. Some of the evidence stems from historical data on the US (see Manacorda, 2006, for evidence and references therein). These studies have found a correlation between the adoption of child labor laws in US states and employment in manufacturing, but the laws tended to follow declines in child labor rather than to lead them. Similar conclusions are obtained in the different context of modern minimum age laws. These laws, passed in many poor countries where child labor is prevalent, seem to be motivated by global political concerns rather than genuine intentions - and are rarely followed by appropriate enforcing actions. ${ }^{1}$ The second reason for seemingly ineffective minimum age laws is the possible difficulty to detect an effect. Standard approaches rely on an 'age trend' approach, i.e. a comparison of child employment rates around the minimum legal age, that may not be precise enough to reveal a potential effect of minimum age legislations (Edmonds, 2014).

Against this background, we suggest new evidence based on a change in the Brazilian law. On the 15th of December 1998, the minimum legal age for work was increased from 14 to 16 . We first show that the reform corresponded to a real intention of the Brazilian government to make it work. Indeed, the law involved a change in the Constitution and, anticipating the ratification of ILO minimum age conventions, was also part of a broad set of measures intended to eradicate child labor in Brazil. Moreover, its enforcement could find support on an operational system of labor inspections that refocused on the detection of illegal labor among children at that period. We nonetheless document the fact that enforcement and compliance may have been heterogeneous across regions and job types.

Secondly, we suggest an empirical approach that is more precise than previous methods to detect potential effects of the reform. Indeed, the literature tends to compare employment rates of children below and above the minimum age, while it is difficult to control for underlying age

\footnotetext{
${ }^{1}$ They are typically based on the principles of the International Labour Organization's minimum age conventions, i.e. Convention C138 on the Minimum Age of Employment and C182 on the Worst Forms of Child Labor. Boockmann (2010) finds little evidence that ILO conventions increase school attendance or decrease child labor.
} 
trends in employment. In our setting, the reform lends itself to discontinuity-based approaches to extract a causal effect of the ban. Precisely, the new ban affected those who turned 14 years old after mid-December 1998 but not those who turned 14 before. Using the Pesquisa Nacional por Amostra de Domicilios (PNAD), we observe these children in September 1999, when they are all aged 14. With regression discontinuity designs (RD), we exploit the discontinuous eligibility for work of these children depending on their birthdate. In difference-in-discontinuity (DDisc), we combine discontinuous treatment and the time change around the threshold.

Our results can be summarized as follows. Both RD and DDisc estimations point to the absence of an overall effect of the new ban on children around 14 years of age. We also find no sign of a reallocation from "visible" firms towards activities that more easily escape inspections (like home-based or outdoor work), nor a substitution of labor within families. Results are robust to extensive sensitivity checks and are not due to a lack of statistical power. Importantly, heterogenous estimations point to a significant drop in child labor among those with highest chances of compliance, namely children in visible activities and in regions characterized by an above-average intensity of labor inspections. We discuss these results in the context of a relatively small literature using natural experiments to identify the potential effect of child labor bans. $^{2}$

\section{Background}

\subsection{Mininum Age Regulation in the Literature}

Minimum age of employment regulations have been one of the most used tools worldwide to combat child labor. Therefore, they have received lots of attention in the theoretical literature on child labor. ${ }^{3}$ In the seminal paper of Basu and Van (1998), there is only one sector of employment for child labor so that a ban can completely prohibit it. Basu (2005) adds a second, unregulated sector. In a two-sector model, enforced minimum age regulations can divert children from regulated activities to non-regulated activities rather than eliminating child employment. In fact, the rise in labor costs to employers induces a lower demand in child labor and lower child wages (an equivalent result is obtained if employers recoup the risk premium by reporting these costs on children wages). Overall child labor may even increase if depressed wages lead budget-constrained households to send more children to work. ${ }^{4}$ This

\footnotetext{
${ }^{2}$ The closest study to ours is Bharadwaj et al. (2013), who exploit changes in the minimum working age in India (see section 2).

${ }^{3}$ This literature includes early contributions by Basu and Van (1998), Ranjan (1999), Baland and Robinson (2000), Dessy (2000), Basu (2005), and Dessy and Pallage (2005).

${ }^{4}$ See Edmonds (2008) for a review of the links between household poverty and child labor.
} 
may also happen if children shifted away from the regulated sector now work in family business and no longer bring external resources. Edmonds and Shrestha (2012) define three necessary conditions for the sector reallocation following a ban in the regulated sector to be neutral on overall child employment: "adults" (i.e. parents or siblings above the minimum age) can move freely between the household and the regulated sector (competitive adult labor markets); adults and children are perfect substitutes subject to a productivity shifter (substitution axiom); the household can freely substitute adult and child labor between productive tasks inside the household (non-saturation).

Empirical analyses are relatively rare. Historical studies focus on high-income countries at the turn of the 19th century and show little effect of minimum age regulations due to their lack of enforcement. For the US, Moehling (1999) examines laws implemented in manufacturing employment between 1890 and 1910. He finds only a small impact on child labor as the enforcement legislation with labor inspections lagged behind the passage of the law. Manacorda (2006) exploits heterogeneity in minimum working ages across US states in 1920. He finds that reaching the eligibility age makes a child more likely to work but not so much because it also simultaneously reduces his siblings' probability of work. These spillovers within families are also emphasized in Bharadwaj et al. (2013), who study the introduction of minimum working age legislation in modern India. Using employment surveys conducted before and after the 1986 law, and age restrictions that determined whom the ban applied to, they show that the relative probability of child employment actually increased. The explanation pertains to a fall in child wages relative to adults' in the industrial, regulated sector, which leads budget constrained households to resort to more work by siblings - or by under-minimum age children themselves when there is no possible sibling substitution. ${ }^{5}$ The most comprehensive study on minimum age regulations in contemporary developing countries is suggested by Edmonds and Shrestha (2012). Using data from 59 low-income countries, they show an absence of discontinuity in child participation in paid-employment around the legal minimum age, suggesting that the enforcement of such restrictions is weak at best.

\subsection{Institutional Context}

Child Labor in Brazil. Brazil is a particularly interesting case study: it has operated a significant shift in its position regarding child labor, from a period of mere tolerance to

\footnotetext{
${ }^{5}$ Another study by Piza and Souza (2016) focuses on the same Brazilian reform as in the present work. Using a difference-in-difference approach, they find a 4 percentage point decrease in informal employment among newly banned boys (but no effect in the formal sector nor for girls). We could not reproduce their results, which may be due to spurious effects capturing an age trend in broad difference-in-difference estimations, as explained in section 3.2 .
} 
a concerted effort to eradicate child work. The strong commitment made by the Brazilian government started in the mid-1990s, after the election of President Cardoso who declared child labor to be "an abhorrent practice and an abuse of human rights". His government displayed a strong intention followed by concrete measures to "wipe out child labor" (Cardoso, 1997). Del Vecchio (2005) cites three main policies undertaken during his mandate: conditional cash transfer programs aimed at encouraging families to keep children in school and/or out of work, inspection and enforcement at the state level directed at child labor, and programs targeted at specific sectors and industries. Child labor has effectively been reduced massively since that time, yet over a broader period - according to PNAD surveys, it was cut by $68 \%$ between 1992 and 2015. ${ }^{6}$ The present study aims to quantify the role played by the change in minimum working age in this context.

The 1998 Reform. The Constitution of 1988 and a specific federal law passed in 1990 (Lei do Estatuto e do Adolescente) had set the minimum legal age of entry in the labor market at 14 years of age. In December 1998, the Brazilian Congress raised the legal minimum working age at 16. This law was enshrined as a change in the Constitution (Constitutional Amendment No. 20). ${ }^{7}$ It was the legal counterpart of redistributive measures aimed to reduce child labour, notably the conditional cash transfers PETI ("program to eradicate child labour", started in 1996) and Bolsa Escola (experimented in 1995-98 in Distrito Federal, then generalized in 2001) as well as improvements in the availability and quality of the school system. The minimum age reform was also a major step to lay the legal framework for combating child labor even before the ratification of ILO conventions C138 on the Minimum Age of Employment (in year 2001) and C182 on the Worst Forms of Child Labor (in year 2000).

Enforcement. Most low and middle-income countries have adopted a minimum age legislation. Yet, while these regulations usually followed external, international pressures, the vast majority of these countries have in effect devoted few resources to enforcing them (Edmonds and Shrestha, 2012). This aspect makes Brazil all the more interesting as it met the conditions of a credible enforcement immediately after the announcement of the reform (Ferro and Kassouf, 2005). As a first concrete measure, the Ministry of Labor and Employment halted issuing

\footnotetext{
${ }^{6}$ This decline is possibly due to the combined effect of labor market reforms, education and social protection reforms as well as to sustained economic growth. There is no real consensus in the academic literature to explain what are the main driving forces (see Rosati, 2011).

${ }^{7}$ An exception was made for the apprenticeship status, which was allowed from 14 years of age (compared to 12 previously). Apprenticeship in Brazil is however a specific programme that involves supervision by specialized vocational training institutions, so that in practice it concerns only a marginal fraction of children. Note also that the law prohibits employees less than 18 from working in unhealthy, dangerous or arduous conditions. Hence hazardous work does not concern the age condition under study.
} 
work permits for youth under 16 years of age on the date of the minimum age reform. A second step consisted in an operational system of labor inspection to detect firms employing children and fine them. Since 1995, the Ministry had included child labor in the agenda of its Labor Inspection Secretariat. It had also set up special task forces of inspectors dedicated to combat child labor (State Committees Against Child Labor), in addition to regional inspection units (Bonfim de Almeida and Kassouf, 2016). Inspectors were regularly trained by the Ministry and their paid was performance-based, with up to $45 \%$ of their wage tied to enforcement efficiency (Almeida and Carneiro, 2009). The administration was therefore prepared and legally equiped when the new law was passed. Following a period focused on the formalization of job, the 1996-98 period is precisely described as one where the reduction of child labor became one of the priorities on inspectors' task list (Coslovsky, 2014).

Heterogeneity. This setting makes it plausible that in the late 1999, at the time PNAD data was collected, the application of the 1998 minimum age law was effective. However, given the characteristics of the Brazilian administration and the nature of children work, it is also likely that its effectiveness was heterogenous. First, due to its large and diverse geographical areas, Brazil's administration, and in particular labor inspections, are decentralized at state and sub-regional levels. Each subdelegacia may have several enforcement offices depending on the size and economic activity of the region. Even if non-random, this disparity is interesting to exploit. In what follows, we shall use a variable drawn from Almeida and Carneiro (2009), namely the proportion of inspectors per firm in a given municipality. ${ }^{8}$

Second, there may be heterogeneity in compliance across different types of child activities. In principle, the Brazilian Constitution does not specify that the minimum age regulation should apply to a particular type of sector or activity. ${ }^{9}$ Yet, in practice, the law is more likely to be binding in some activities that are more visible or exposed to detection, and less so in homebased or outdoor work. This distinction will be analyzed hereafter. Note that it will differ from the traditional division between formal and informal labor. Indeed, many large (hence visible) firms in Brazil employ workers deemed informal in the sense that they do not hold a labor card or contribute to the social system (Bargain and Kwenda, 2014). We will simply explore the formal-informal divide as a sensitivity check.

\footnotetext{
${ }^{8}$ Almeida and Carneiro (2009) analyzed the effects of enforcing employment regulations on employment, production, sales and capital stock in Brazil. The study considers the fact that labor regulations are not enforced uniformly in Brazil. In a subsequent study, Almeida and Carneiro (2012) analyzed the impact of labor inspections on formal and informal employment. In both studies, the proportion of inspectors is used to measure the potential enforcement of labor market regulations.

${ }^{9}$ This is in contrast with the ILO C138 convention, which explicitly excludes work inside the family, or the 1986 Indian Child Labour Prohibition and Regulation Act studied by Bharadwaj et al. (2013), which exempts agriculture and family-run businesses.
} 
Finally, note that enforcement heterogeneity is likely to be non-random and possibly correlated to the distribution of child activities. For instance, inspectors may have an incentive to focus on zones where more exposed firms are present. This is not an issue for our identification strategy since there is no reason for inspection density to vary with child birthdays in the data. As for the potential reallocation of children across activities, this is precisely what we check hereafter by decomposing the effect primarily between visible and less visible activities.

\section{Data and Empirical Approach}

\subsection{Data and Selection}

We use the Pesquisa Nacional por Amostra de Domicilios (PNAD), collected at the end of September every year. The PNAD is the largest household survey in Brazil, covering around 350, 000 individuals per year and containing usual socio-demographic information and the labor market status of every family member. From the data, we construct several samples of children depending on their birthdate, as described below. The PNAD data reports information about the exact birthdays of each child. We have checked the consistency of this variable and dropped children with missing values or obvious problems regarding birthdate. ${ }^{10}$ We keep households whose head was between 18 and 60 years of age. In Figure 2, we report time trends in the rate of economically active children using this selection. It shows higher rates of employment among older children and a broad decline in child labor over the period, possibly reflecting the combined effect of various policy measures as discussed above. The employment rate of children aged 14-15 only slightly decreases between 1998 and 1999, and without a marked differential compared to children aged 12-13. This simple observation does not allow concluding about the potential effects of the reform given it is based on broad age groups.

Selection for RD. Our RD analysis focuses on the PNAD data collected the year following the reform, i.e. the wave of September 1999. We focus on children who turned 14 years old around mid-December 1998. For our main RD estimation, we retain children born in a \pm 3 month bandwidth around the cutoff. That is, we select the 6-month cohort of children who turned 14 between 3 months before the 15th of December 1998 and 3 months after. This sample comprises 3, 007 children, representing 1,392,634 children when population weights are used. Note that all our estimations will make use of sample weights (Silva et al., 2002, UNESCO, 2017).

\footnotetext{
${ }^{10}$ These problematic cases, due to rounding errors, amount to only $1.8 \%$ of the sample of households with children.
} 
Figure 1: Trends in Child Labor in Brazil

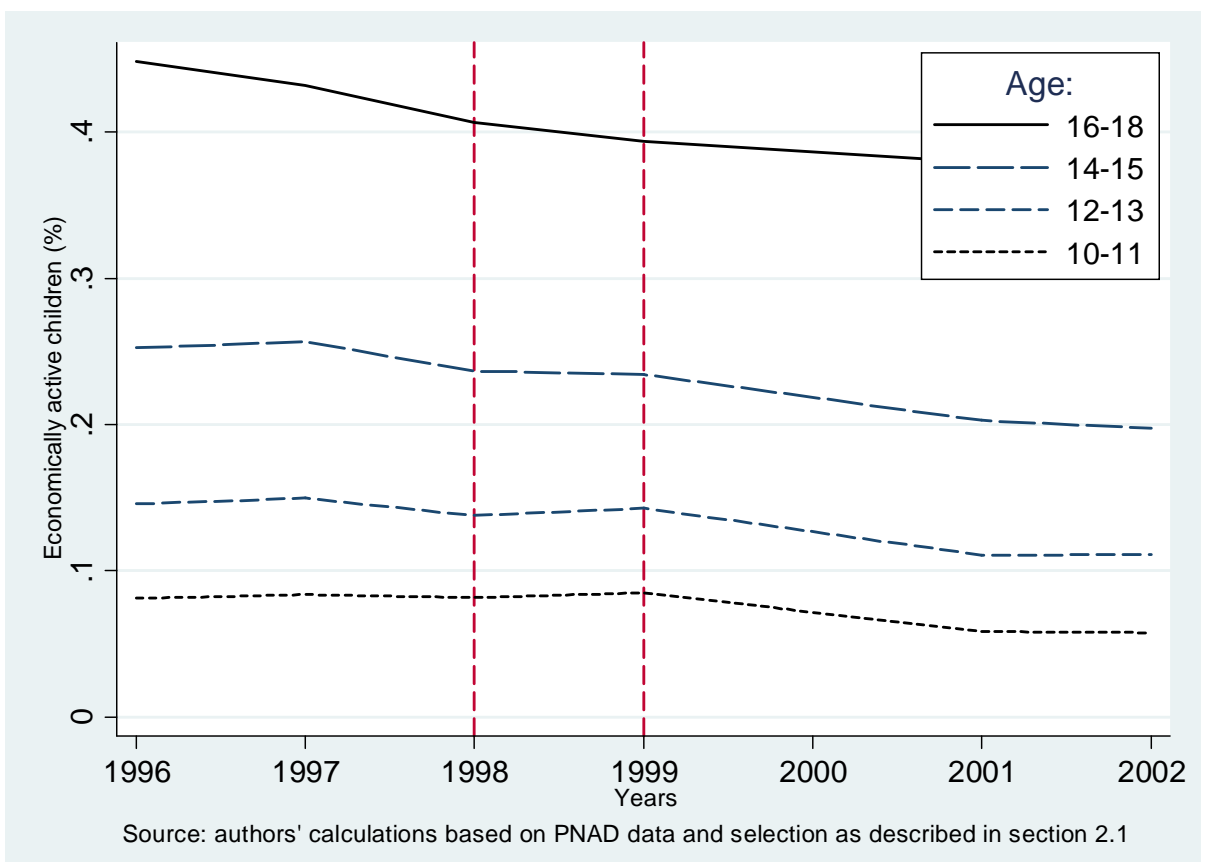

Selection for DDisc. For DDisc estimations, we add data from September 1998 (3 months before the new ban), using two alternative definitions of the placebo group. The first one comprises children of the same cohort as our RD selection, i.e. born between mid-September 1984 and mid-March 1985. This selection comprises an additional 2, 971 children (representing 1,364,225 children), making the 1998 and 1999 data well balanced. The second one is the previous-cohort children, born between mid-September 1983 and mid-March 1984, which also adds a balanced group of 2, 922 observations (representing 1,349, 511 children). Table 1 describes how these groups are used for identification when 1998 data are added for DDisc estimations. The same-cohort approach is described in the left panel, comparing the children of our main cohort of interest observed 3 months before the reform (September 1998, upper-left panel) and observed 9 months after (September 1999, bottom-left panel). In the former group, none of the children are allowed to work as they are subject to the old ban; in the latter, only those turning 14 before mid-December 1998 are eligible to work under the new ban in September 1999. The same-age approach described in the right panel of Table 1 compares two cohorts born \pm 3 months around mid-December 1983 (for observations in Sept. 1998, upper-right panel) or around mid-December 1984 (for our main group observed in Sept. 1999, lower-right panel). All were 14 at the time of observation, so only those born after mid-December 1984 are subject to a minimum age ban. In sensitivity analyses, we will also experiment with a \pm 6 month 
bandwidth. As explained in the Appendix Table A.1, this broader selection is valid with the same-age approach, but less so with the same-cohort approach. ${ }^{11}$

Table 1: Treatment and Control Groups with the +/- 3 Months Window

\begin{tabular}{|c|c|c|c|}
\hline \multicolumn{4}{|c|}{ Same cohort, consecutive ages } \\
\hline \multirow[b]{2}{*}{ Cohort definition } & \multicolumn{3}{|c|}{ PNAD $1998(\mathrm{n}=2,971)$} \\
\hline & $\begin{array}{c}\text { age in } \\
\text { Sept. } 98\end{array}$ & $\begin{array}{l}\text { subject to subject to } \\
\text { old ban new ban }\end{array}$ & $\begin{array}{l}\text { allowed } \\
\text { to work }\end{array}$ \\
\hline $\begin{array}{l}\text { Turned } 14 \text { between Dec } 151998 \\
\text { and Mars } 151999\end{array}$ & 13 & yes & no \\
\hline $\begin{array}{l}\text { Turned } 14 \text { between Sept } 151998 \\
\text { and Dec } 151998\end{array}$ & 13 & yes & no \\
\hline
\end{tabular}

PNAD $1999(\mathrm{n}=3,007)$

\begin{tabular}{|c|c|c|c|c|}
\hline Cohort definition & $\begin{array}{l}\text { age in } \\
\text { Sept. } 99\end{array}$ & $\begin{array}{l}\text { subject to } \\
\text { old ban }\end{array}$ & $\begin{array}{l}\text { subject to } \\
\text { new ban }\end{array}$ & $\begin{array}{l}\text { allowed } \\
\text { to work }\end{array}$ \\
\hline $\begin{array}{l}\text { Turned } 14 \text { between Dec } 151998 \\
\text { and Mars } 151999\end{array}$ & 14 & - & yes & no \\
\hline $\begin{array}{l}\text { Turned } 14 \text { between Sept } 151998 \\
\text { and Dec } 151998\end{array}$ & 14 & - & no & yes \\
\hline
\end{tabular}

Treatment "banned from work due to minimal age condition" indicated in grey (due to old ban in 1998 and to new ban for the first half-cohort in 1999)

\begin{tabular}{|c|c|c|c|c|}
\hline \multicolumn{5}{|c|}{ Same age, consecutive cohorts } \\
\hline \multirow[b]{2}{*}{ Cohort definition } & \multicolumn{4}{|c|}{ PNAD $1998(\mathrm{n}=2,922)$} \\
\hline & $\begin{array}{c}\text { age in } \\
\text { Sept. } 98\end{array}$ & $\begin{array}{l}\text { subject to } \\
\text { old ban }\end{array}$ & $\begin{array}{l}\text { subject to } \\
\text { new ban }\end{array}$ & $\begin{array}{l}\text { allowed } \\
\text { to work }\end{array}$ \\
\hline $\begin{array}{l}\text { Turned } 14 \text { between Dec } 151997 \\
\text { and Mars } 151998\end{array}$ & 14 & no & - & yes \\
\hline $\begin{array}{l}\text { Turned } 14 \text { between Sept } 151997 \\
\text { and Dec } 151997\end{array}$ & 14 & no & - & yes \\
\hline
\end{tabular}

\begin{tabular}{|c|c|c|c|c|}
\hline Cohort definition & $\begin{array}{l}\text { age in } \\
\text { Sept. } 99\end{array}$ & $\begin{array}{l}\text { subject to } \\
\text { old ban }\end{array}$ & $\begin{array}{l}\text { subject to } \\
\text { new ban }\end{array}$ & $\begin{array}{l}\text { allowed } \\
\text { to work }\end{array}$ \\
\hline $\begin{array}{l}\text { Turned } 14 \text { between Dec } 151998 \\
\text { and Mars } 151999\end{array}$ & 14 & - & yes & no \\
\hline $\begin{array}{l}\text { Turned } 14 \text { between Sept } 151998 \\
\text { and Dec } 151998\end{array}$ & 14 & - & no & yes \\
\hline
\end{tabular}

Treatment "banned from work due to minimal age condition" indicated in grey (due to new ban for the first half-cohort in 1999)

Child Labor Definitions and Sectors. Our main outcome is a child labor market participation dummy. It refers to economically active children, defined as children performing paid or unpaid work for their own family or others. This definition excludes children only performing household chores inside the family. The main heterogeneity we shall tackle in our estimation pertains to the more or less visible nature of child employment, which should condition the probability of compliance with the new law. We simply construct two groups based on work location among economically active children: "visible" child laborers comprise those working in stores, factories or farms, while "invisible" workers are home-based (be it an employer's home or their family's) or outdoor (in a vehicle or on the street). For sensitivity checks, we will also distinguish other types of activities: paid versus unpaid work and formal versus informal paid employment (even if the formality distinction, as argued above, is not so relevant in the

\footnotetext{
${ }^{11}$ As seen in this table, the 'control' year 1998 is a mix of banned and unbanned children under the old system. Indeed, those born between June 15 and September 15 1984, excluded from our selection, are already 14 and hence eligible for work under the old regime. This problem does not apply with the 3-month bandwidth, whereby the children of our cohort of interest are between 13 and a half and exactly 14 when observed in September 1998 (hence, homogeneously forbidden to work under the old regime, whether born before or after mid-December).
} 
present context). Formal employment is based on a standard definition, i.e. holding a labor card (carteira assinada) or contributing to the social security (Henley et al., 2009).

Enforcement: Inspection Data. We shall also check heterogeneity in enforcement using administrative data on labor regulations, as collected by the Department of Inspections at the Ministry of Labor for the project of Almeida and Carneiro (2009). This data contains different variables regarding the number and location of regional labor offices, the number of inspectors, or the municipal rate of inspection per firm. For each household, we impute the latter variable, calculated as the log number of inspections multiplied by 100 and divided by the number of firms. Since municipality information is not available in PNAD, we simply use mean intensities of inspection at state level (or at slighltly more disaggregated levels using rural/urban variation). The information is available for the year 2002, which is around two years later than PNAD data at use. Arguably, the distribution of the administrative workforce did not change much over the 2000-2002 period. Hence this information can be seen as a reasonable proxy for the intensity of inspection in the autumn 1999. In any case, we will use this variable only for suggestive evidence of the potentially heteregeneous effect of the law.

\subsection{Empirical Approaches}

Regression Discontinuity (RD). Given the clear cutoff of the reform and the precise birthdate information available in PNAD, a natural setting is the RD design. It requires only crosssectional observations of the cohort born around mid-December 1984 once the reform is in place (September 1999). If the ban is effective, a discontinuous drop in child employment should be observed at the cutoff. As argued by Imbens and Lemieux (2008), the graphical inspection of the potential discontinuity should be an integral part of any RD analysis. For that purpose, we will graphically represent mean employment outcomes by birthdate cells expressed in weeks (see Lemieux and Milligan, 2008). For estimations, we will use birthdate (the running variable $\tau_{i}$ ) expressed in days. We denote $Y_{i}$ the outcome (labor supply) for a child $i$ born at date $\tau_{i}$ and the treatment variable $1\left(\tau_{i}>m i d D e c\right)$, equal to 1 if the child is born after mid-December. The parametric model estimated on 1999 data is written:

$$
Y_{i}=\alpha_{0}+X_{i t} \alpha_{1}+\beta^{R D} .1\left(\tau_{i}>\operatorname{midDec}\right)+\delta\left(\tau_{i}\right)+\eta_{i \tau}
$$

where $\beta$ captures the potential employment effect of the ban, identified by discontinuous eligibility among similar children. ${ }^{12}$ The key identification assumption is that $\delta(\cdot)$ is a continuous

\footnotetext{
${ }^{12}$ Identification stems from the assumption that children born just before and just after the reform date are quasi-identical. Naturally, the more we depart from the cutoff, the more fragile this assumption is. This illustrates the fundamental difference in identification with approaches like double differences. This also gives more credit, but less precision, to a narrow bandwith such as our \pm 3 month window.
} 
function, i.e. child labor has no reason to vary discontinuously with birthdate. Function $\delta(\cdot)$ should certainly be flexible enough to accommodate nonlinearities due to age or subcohort heterogeneities around the cutoff. Yet it is not necessary to impose a particular form on this employment-age relationship: we can simply use alternative flexible forms and check that the results are broadly unchanged whatever the specification used. Note that covariates $X_{i t}$ can be added, which improve the efficiency of the estimation but are not necessary for identification. They include child gender, ethnicity, household head's age, gender and years of schooling, household's wealth and region. In Appendix A.2, we check that these characteristics are very similar on both sides of the discontinuity, either using the baseline 6-month bandwidth or even a broader 12-month bandwidth. Finally, note that $Y_{i}$ will simply be a dummy for child work in our estimations so that the model will be estimated by linear probability model, with standard errors clustered at birthdate cell level.

Discussion. $\mathrm{RD}$ is based on the idea that the forcing variable makes the assignment to treatment 'as good as random' in the neighborhood of the discontinuity (Lee and Lemieux, 2010). This is the case with birthdate if we believe that children born before a mid-December are not different from those born after. Clearly, there is no possible anticipation of the reform, which was not announced, and no real anticipated action that could have been taken (given that the running variable is birthdate). The main potential issues go as follows. First, there could be differences between children stemming from shocks that might have occurred around mid-December 1984. We come back to this point when we discuss the advantages of the DDisc design. Second, there might be concerns about the age declaration of children. If there is misreporting only to potential employers but not in PNAD data, then these are just cases of noncompliance that can affect the effectiveness of the treatment. If misdeclarations also concern the birthdates reported in PNAD, we face cases of manipulation of the running variable, which we check for in Appendix A.3. Finally, we assume to be in presence of a sharp RD design. Coefficient $\beta^{R D}$ simply captures the extent to which the new minimum working age is enforced by the state and respected by families and employers. As described in section 2.2, there was no ambiguity about the application of the law or its timing. ${ }^{13}$

\footnotetext{
${ }^{13} \mathrm{~A}$ fuzzy RD design would imply that we are able to distinguish between assignment to treatment (birthdate) and the treatment itself, which is conceptually difficult to define. Treatment can be seen as being aware of one's age and of the law, i.e. of being able to respond to the law. Then, "never-takers" would be confined to groups of the population who do not hold birth certificate and/or possibly live in remote areas. Another reason for fuzzyness in treatment is the presence of measurement errors in age declaration. This type of issue usually comes from rounding errors by using age in year (Dong, 2015), which is not our case. Moreover, given the identification at the threshold, errors on birthday declaration in the data would not affect the conclusions if these errors are uniformly distributed (we would simply measure an intention-to-treat due to missclassification of children in treated and control groups). However, if errors are discontinuously distributed around the cutoff, which may
} 
Difference-in-Discontinuity (DDisc). With the Difference-in-Discontinuity (DDisc), it is possible to combine the advantages of a RD design, notably the identification around the cutoff, with those of a difference-in-difference (DD), i.e. exploiting the time change due to the reform. Graphically, it will simply be represented as a differential RD, i.e. the difference in employment rate by birthdate cells (again in weeks) between September 1999 and September 1998. Statistical estimations are conducted on pooled data for 1998 and 1999. The DDisc model is written:

$$
\begin{aligned}
Y_{i t} & =\alpha_{0}+X_{i t} \alpha_{1}+\lambda_{1}^{\text {DDisc }} \cdot 1\left(\tau_{i}>\text { midDec }\right)+\lambda_{2}^{\text {Disc }} .1(t=1999) \\
+\beta^{D D i s c} \cdot 1\left(\tau_{i}\right. & >m i d D e c) \cdot 1(t=1999)+\delta_{t}\left(\tau_{i}\right)+\eta_{i \tau t} .
\end{aligned}
$$

Here, the dummy $1\left(\tau_{i}>\right.$ midDec $)$ captures only the birthdate effect, i.e. whether a child is born after mid-December of any year (hence potential seasonality in child labor). The dummy $1(t=1999)$ is a mere time effect that may capture business cycles. As in difference-in-difference (DD), the treatment effect $\beta^{\text {Disc }}$ corresponds to their interaction, i.e. being subject to the new ban. Taking the time difference, we obtain:

$$
\Delta Y_{i \tau}=\left(\lambda_{2}^{D i s c}+\Delta X_{i t} \alpha_{1}\right)+\beta^{D D i s c} \cdot 1\left(\tau_{i}>\operatorname{midDec}\right)+\Delta \delta\left(\tau_{i}\right)+\Delta \eta_{i t \tau},
$$

where $\Delta Y_{i \tau}$ is the difference in outcome between 1999 and 1998, and $\Delta \delta\left(\tau_{i}\right)$ a polynomial form of the same specification as $\delta\left(\tau_{i}\right)$ in the RD design. ${ }^{14}$ The treatment effect captures the time variation in the employment discontinuity around the birthdate cutoff. The time change can be evaluated against the previous year's employment level of the same cohort (same-cohort approach) or against the previous cohort's employment level taken at the same age (same-age approach). The 1998 backdrop corresponds to a situation where, under the old regime, everyone was below 14 and hence ineligible for work (same-cohort approach) or above 14 and allowed to work (same-age approach), as described in Table 1.

Advantages over Age Trends Methods, DD and RD. This approach usually overcomes several shortcomings of RD and DD methods (Grembi et al., 2016, Somers et al., 2013). It can also be compared to other methods used to analyze minimum age legislations. In general, this literature tends to compare employment rates of children below and above the minimum age while controlling for age trends in employment using employment rates at younger age (Edmonds and Shreta, 2012). As stated by Edmonds (2014), this approach answers "only the question of what would happen to paid employment if minimum age of employment regulations

be caused by misreporting to PNAD interviewers, this justifies the specific check provided in Appendix A.3.

${ }^{14}$ This is easily illustrated. For instance, take a linear spline of the form $\delta_{t}\left(\tau_{i}\right)=\delta_{t}^{\text {left }} .1\left(\tau_{i} \leq 0\right) \cdot \tau_{i}+$ $\delta_{t}^{r i g h t} .1\left(\tau_{i}>0\right) \cdot \tau_{i}$. It gives a time demeaned term $\Delta \delta\left(\tau_{i}\right)=\Delta \delta^{l e f t} \cdot 1\left(\tau_{i} \leq 0\right) \cdot \tau_{i}+\Delta \delta^{r i g h t} \cdot 1\left(\tau_{i}>0\right) \cdot \tau_{i}$ with $\Delta \delta^{k}=\delta_{1999}^{k}-\delta_{1998}^{k}$ for $k=$ left, right. 
were extended an additional year. If minimum age laws shift the entire age distribution of employment, or have gradual, cumulative effects on employment, this approach could not detect these effects. The limited question considered in these studies could be resolved by focusing on countries that change their laws".

This is precisely what we do in the DDisc. Exploiting a change in the minimum age is also the idea behind DD. Yet, DD estimations face the aforementioned difficulties related to age trends in employment. Indeed, they suggest only broad comparisons of those under and over 14 at the cutoff. ${ }^{15}$ Using the same-age approach, DD estimations control for the "natural" relationship between employment and age, yet on the basis of different cohorts (which may have experienced different phasing-in of conditional cash transfers, or are just at different points on a secular declining trend of child labor). Using the same-cohort approach, they control for such a relationship as proxied by children who are a year younger. In this case, it is a very similar procedure to the 'age trend' approach described above: it is not clear at all if the employment growth at age 12-13 can be used as a valid trend for that at age 13-14.

Crucially, in the DDisc, identification takes place around the cutoff and is therefore less affected by different age trends. Furthermore, time-varying unobservables can defeat identification in DD analyses. RD and especially DDisc escape these caveats since identification is provided by the assumption of continuity of unobservable factors that determine child work around the cutoff. Compared to DD, they considerably limit the role of unobservable heterogeneities between treated and control groups since these groups are most similar near the cutoff. Formally, it is easy to show that the essential difference between DD and DDisc estimations: the latter

\footnotetext{
${ }^{15}$ Lemieux and Milligan (2008) show the possible sensitivity of DD estimates to the control group definition and compare them to results from RD designs. See also Bertrand et al. (2004) for a thorough analysis of the validity of $\mathrm{DD}$.
} 
control (in a flexible way) for the smooth employment-age function around the cutoff. ${ }^{16}$

Compared to RD estimations for 1999, the DDisc nets out potential pre-existing differences between the subcohorts on each side of the mid-December 1984 birthdate. Hence, it does not require the absence of other time changes, like co-treatments, at the cutoff - only that the effect of any co-treatment remains constant between the pre- and post-reform periods. In our case, the RD interpretation may be defeated by specific shocks for those born on one side of the birthdate cutoff, for instance weather shocks (severe flooding in Brazil in January 1985) or macro/political shocks (for example an acceleration of democratic changes in the early 1985). We may also argue that other policy events can take place around the reform date (for instance entering a new civil year, with application of policy measures voted the year before).

\section{Results}

\subsection{Baseline Results}

Graphical Evidence: Main Results. The first step of our RD analysis consists of a visual inspection of the employment-birthdate relationship around the reform cutoff. We focus on the 6-month bandwidth selection. In the upper part of Figure 2, we plot average child employment rates by birthdate cells (in weeks) around mid-December 1984 using employment status in September 1998 (left-hand side graph) and September 1999 (right-hand side). We also show quadratic spline trends in employment rates (left-hand side axis) with dashed lines representing the $95 \%$ confidence intervals. Upper lines with crosses show age levels for each birthdate cell (right-hand side axis).

\footnotetext{
${ }^{16}$ A standard DD model is written:

$$
Y_{i t}=\alpha_{0}^{D D}+X_{i t} \alpha_{1}^{D D}+\lambda_{1}^{D D} .1\left(\tau_{i}>\operatorname{midDec}\right)+\lambda_{2}^{D D} .1(t=1999)+\beta^{D D} .1\left(\tau_{i}>\operatorname{midDec}\right) .1(t=1999)+\varepsilon_{i t}
$$
}

with coefficient $\beta^{D D}$ capturing the heterogenous treatment status in September 1999 relatively to the 1998 situation. In time-demeaned form, it gives:

$$
\Delta Y_{i t}=\left(\alpha_{3}+\Delta X_{i t} \alpha_{1}\right)+\beta .1\left(\tau_{i}>\operatorname{midDec}\right)+\Delta \varepsilon_{i t}
$$

so the main difference with DDisc designs is that the DD does not control for the continuous relationship between the outcome and the running variable, i.e. it does not identify the effect locally. This is true even if $\tau_{i}$ is included in the set of characteristics $X_{i t}$ in the DD, since it is netted out. Assume that we now interact it with time. We simply replace $X_{i t} \alpha_{1}$ by $X_{i t} \alpha_{1}+\alpha_{1 t}^{\prime} \tau_{i}$ and obtain:

$$
\Delta Y_{i t}=\left(\alpha_{3}+\Delta X_{i t} \alpha_{1}\right)+\beta .1\left(\tau_{i}<\operatorname{midDec}\right)+\left(\alpha_{1,99}^{\prime}-\alpha_{1,98}^{\prime}\right) \tau_{i}+\Delta \varepsilon_{i t},
$$

which boils down to a linear form of the parametric DDisc model, i.e. a quite restrictive one. 
In the first graph, the pattern for year 1998 reflects the relationship between child labor and age in the absence of a ban, for children aged between 13.5 and 14 years old. We expect no discontinuous change around the cutoff in that year (except those that might have arisen from other possible confounding policies or events). The graph for 1999 depicts the distribution of employment rates for the same cohort of children one year later, when the new ban is effective for those to the right of the cutoff. Clearly, we cannot distinguish any drop in employment for the latter : all the birthdate cells to the right are relatively well aligned with those to the left. Thus there is no evidence of an overall employment effect of the new ban.

Figure 2: RD and Same-cohort DDisc: Graphical Evidence (Total Employment)

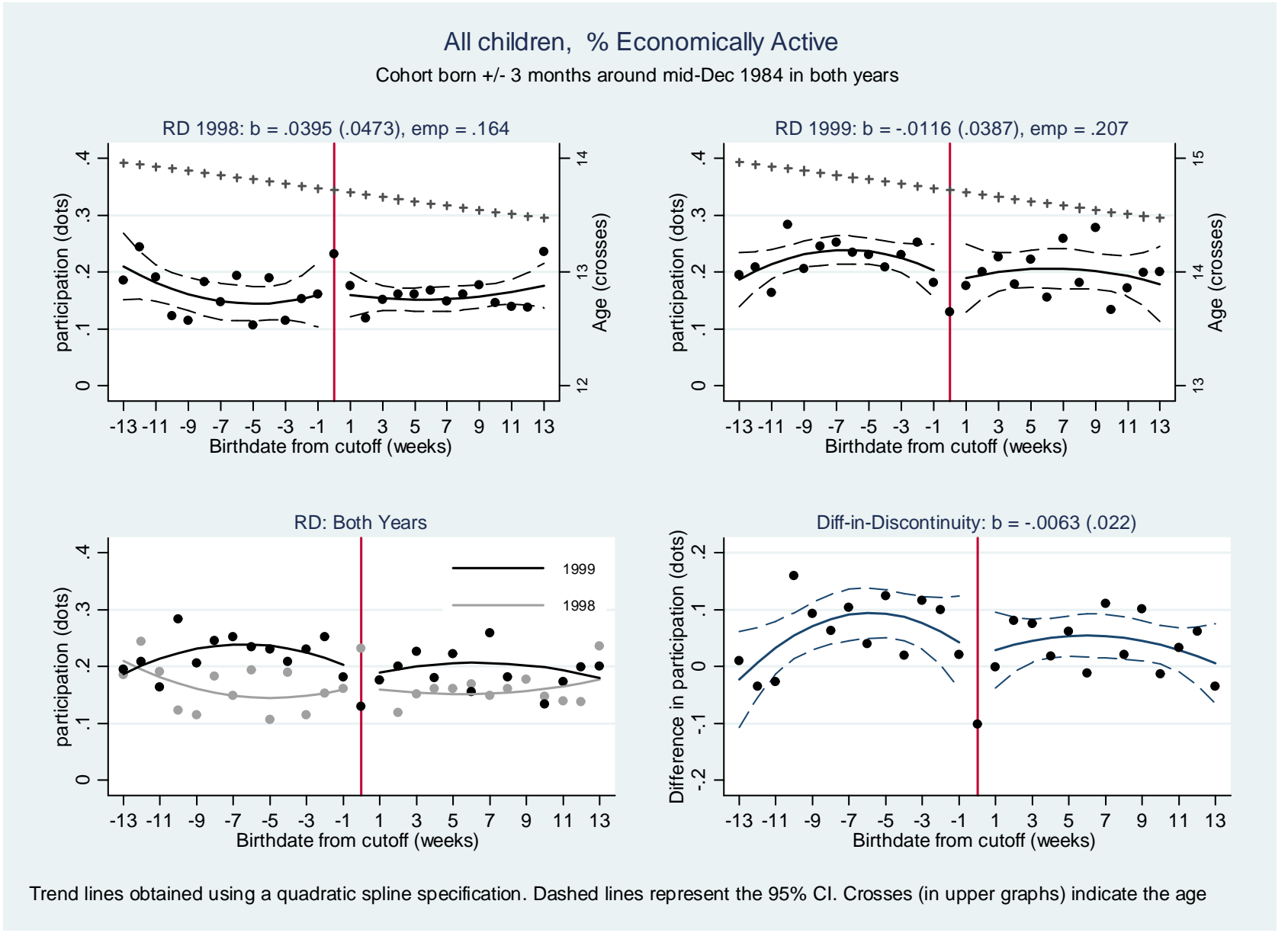

The age of children observed in September 1999 increases from 14.5 (when born 3 months after the cutoff) to 15 years old (when born 3 months before). Consistently, we can distinguish a slight increase in employment as age increases (i.e. when moving from the right to the left). This is more easily seen in the bottom left quadrant, where we pool data for both years to 
compare employment levels. It turns out that the trend for 1998 is flatter: the difference in employment trends for the same cohort a year apart increases with age. As a result, the time difference for the non-treated (the difference between the two curves to the left of the cutoff) is larger than the time difference of the treated (the difference to the right). This illustrates well our point above: DD estimates may wrongly point to an effect of the ban if child employment naturally accelerates with age. The apparent acceleration may also result from an increase in child labor among elder children not affected by the ban in 1999 (Bharadwaj et al., 2013). We turn back to this point below.

The last graph at the bottom-right shows the difference in employment rate for each birthdate cell between 1999 and 1998, based on the same-cohort approach. This graphical representation of the DDisc allows detecting a potential gap at the cutoff that would be caused by heterogenous treatment status around the cutoff when we net out the $1999 \mathrm{RD}$ from the employmentbirthdate relationship a year before. Hence, this graph is purged from potential time-invariant heterogeneity between subcohorts on each side of the cutoff (and from pre-existing confounding policies or events that also create differences in employment around mid-December). We observe no significant discontinuous change in child labor around the threshold. We believe that these graphical checks are convincing of the fact that there is no obvious effect of the ban on overall child employment.

In Appendix Figure A.2, we produce similar results using the same-age placebo group for the year 1998. ${ }^{17}$ The DDisc graph now compares our main cohort (born around mid-December 1984) in September 1999 with the previous cohort (born around mid-December 1983) in September 1998, i.e. exactly one year before and hence at the very same ages (between 14.5 and 15 years old, reading the graphs from right to left). This time, there is no particular difference in the age pattern of employment, and in particular no larger increase in child employment rate for those furthest above the threshold. This confirms the absence of an overall effect of the new legislation. It also conveys that there is no particular compensating increase in labor supply by older siblings (at least those aged 14) in 1999.

Graphical Evidence: by Employment Type. In Figure 3, we split the samples used for graphical analyses with the same-cohort DDisc between different types of job categorization. The main one in the upper panel considers different workplace types. As discussed in section 2.2 , we focus on the employment rate of children in visible activities (left-hand side), such as work in shops, factories or farms. We compare it to employment in activities less exposed to enforcement because of a less detectable nature, namely work within homes or outdoor.

\footnotetext{
${ }^{17}$ Note that $1998 \mathrm{RD}$ graphs in both Figures 2 and A.2 tend to validate the smoothness assumption around the mid-December cutoff.
} 
Figure 3: DDisc (same-cohort): Graphical Evidence (by workplace type)

\section{By workplace type}

Visible workplaces (shops, factories, farms)

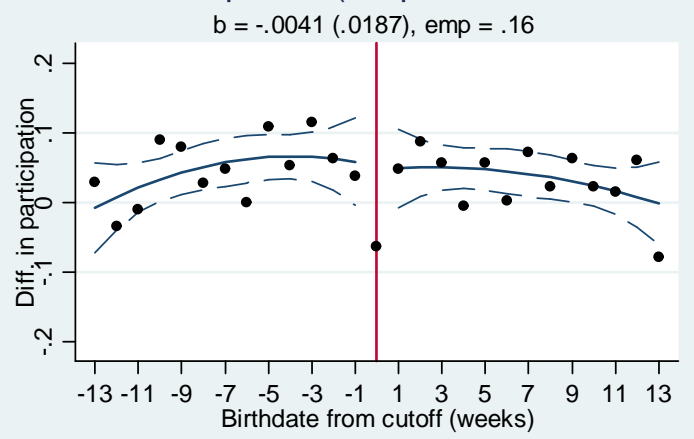

Less visible places (homes and outdoor)

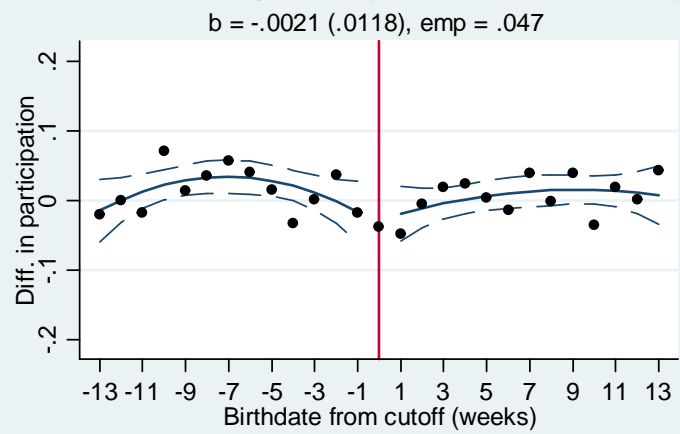

By standard categorization: paid vs unpaid

\section{Paid}

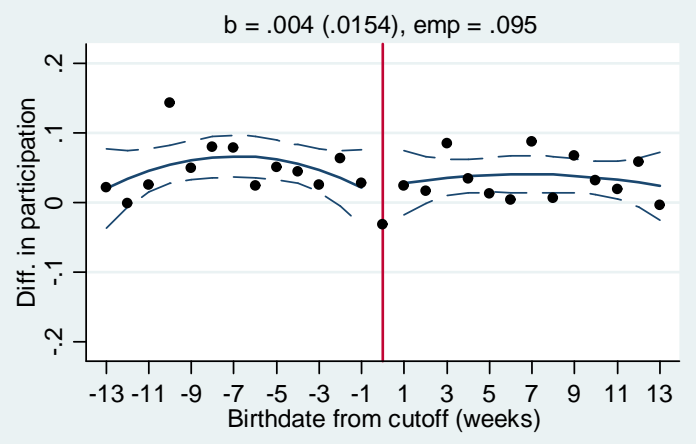

Unpaid $\mathrm{b}=-.0116(.0168), \mathrm{emp}=.129$

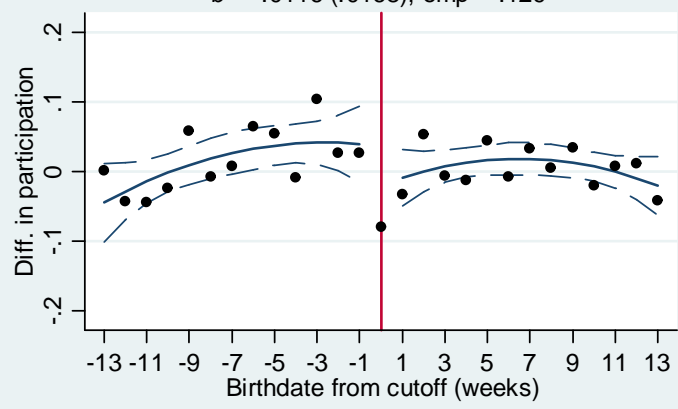

By standard categorization: formal vs informal

Paid \& formal

$\mathrm{b}=-.0025(.0039), \mathrm{emp}=.006$

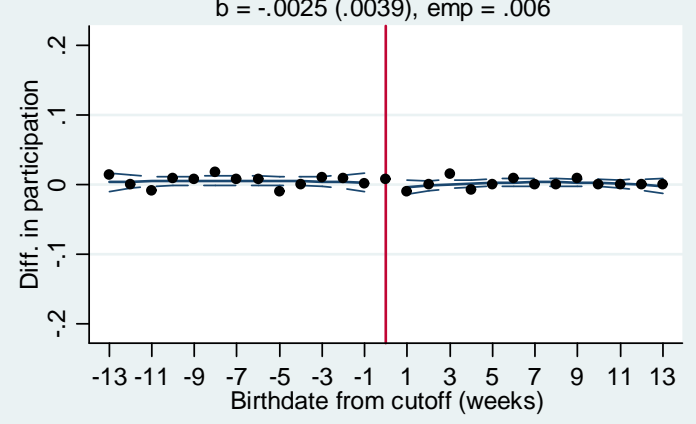

Paid \& informal $\mathrm{b}=.0065$ (.0145), emp $=.089$

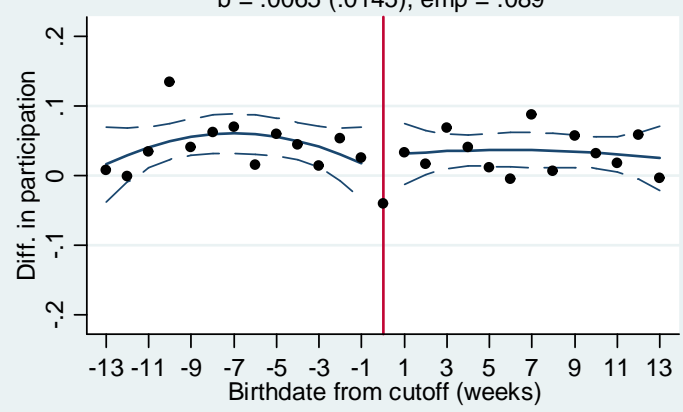


In all cases, graphical evidence shows that the effect of the new ban was not effective, not even in visible activities where the law has more chances to be respected. The other categorizations in Figure 3 are more standard: paid versus unpaid work and formal versus informal paid work. Results corroborate previous findings about the absence of an employment effect of the ban.

Table 2: Estimates based on Discontinuity in Treatment

\begin{tabular}{lcccc}
\hline \hline Type & Bandwidth & $\begin{array}{c}\text { RD } \\
\text { (Sept. 1999) }\end{array}$ & $\begin{array}{c}\text { DDisc } \\
\text { (same cohort) }\end{array}$ & $\begin{array}{c}\text { DDisc } \\
\text { (same age) }\end{array}$ \\
\hline Overall employment & $+/-3$ & -0.0116 & -0.00628 & 0.0314 \\
Overall employment & $+/-6$ & $(0.0387)$ & $(0.0220)$ & $(0.0201)$ \\
Visible employment & + - & $(0.0345$ & 0.000570 & $0.0298^{* *}$ \\
Less visible employment & $+/-3$ & -0.0215 & -0.00413 & 0.0118 \\
Overall empl., urban & $+/-3$ & 0.00981 & -0.00215 & 0.0196 \\
& & $(0.0221)$ & $(0.0118)$ & $(0.0124)$ \\
Visible empl., urban & $+/-3$ & 0.00878 & -0.00370 & 0.0290 \\
& & $(0.0420)$ & $(0.0219)$ & $(0.0226)$ \\
Less visible empl., urban & $+/-3$ & $(0.00136$ & -0.00447 & 0.00522 \\
& & 0.00742 & 0.000762 & $0.0238^{*}$ \\
\hline
\end{tabular}

$\mathrm{RD}$ : regression discontinuity, DDisc: difference-in-discontinuity. Estimations are based on a quadratic spline function of the running variable (sensitivity analysis is provided in the Appendix). Std errors in brackets. $*, * *, * * *$ indicate significance levels at $10 \%, 5 \%, 1 \%$. Controls are child gender, ethnicity, household head's age, gender and years of schooling, region, rural, metropolitan area, assets, rate of inspection, home ownership, household size. The R-squared is around 0.13 in RD and 0.15 in DDisc estimations with the 6-month bandwidth.

Estimations. The main estimation results are gathered in Table 2. We report the estimates of $\beta$ for the RD design (equation 1) carried out on 1999 data. We also present estimates of the DDisc (equation 2) on pooled data, using either the same-cohort or the same-age comparison groups for year 1998. Estimates are obtained with a quadratic spline specification of the smooth function $\delta(\cdot)$. The first row shows results with the 6 -month bandwidth. Both RD and DDisc approaches corroborate graphical evidence: we find no sign of a change in employment among children subject to the ban. The second row gives similar result with the broader bandwidth. Then we distinguish visible and less visible activities. The former type of child employment yields a negative effect with RD and same-cohort DDisc, twice larger than the effect for less 
detectable activities. In both cases, however, these effects are not statistically significant. Finally, we replicate the estimations for urban children only ( $81.7 \%$ of the initial sample). These are more likely to be employed in large firms with higher chances of inspection. We observe no major difference in this case compared to results on the sample pooling rural and urban households. In the Appendix, Table A.3 shows estimates for alternative specifications of $\delta(\cdot)$ (linear, quadratic, cubic, linear spline), again with no particular difference with the baseline estimates described above.

\subsection{Power Calculations}

A genuine concern pertains to the ability of our estimations to detect a significant effect of the ban on child labor at the discontinuity. We carry out power calculation for RD and DDisc designs (see Cattaneo et al., 2017, Schochet, 2008). In both case, the precision of estimated treatment effects is typically expressed in terms of minimum detectable effect (MDE), i.e. the smallest true treatment effect that has a reasonable chance (usually a power of $80 \%$ ) of producing an estimated treatment effect that is statistically significant at the $5 \%$ level. We will report MDE in percentage of the control group outcome (the employment rate of children turning 14 just before the reform) as well as standardized MDE (MDE in percentage of the standard deviation of the control group outcome). ${ }^{18}$

Results are presented in Figure 4. We focus on our favorite model, the DDisc design, and report power levels for different bandwiths (6 or 12 months) and different definitions of the placebo group (same-cohort or same-age children in 1998). In all cases, power increases with the size of the effect we want to detect (expressed in percentage of the control group mean outcome). At the usual level of $80 \%$, the 6 -month bandwidth model using the same-cohort placebo can detect an effect no smaller than $27 \%$ of the unbanned children's employment rate. In this case, we obtain a standardized MDE of $14 \%$, which is relatively small. The precision is best with a large bandwidth and the same-age comparison group. In this case, we can detect a change in child labor of at least $17 \%$ of the control group's mean outcome (and a standardized MDE of $10 \%$ ). While these results apply to the overall employment effect, we have replicated power calculations for the other cases described above. In particular for the visible sector, in which we would expect more compliance to the ban, results are slightly less precise due to the smaller size

${ }^{18}$ Formally, the MDE for a RD design is defined as:

$$
M D E=2.8\left(\frac{\left(1-R_{Y}^{2}\right) \sigma_{Y}^{2}}{N P(1-P)\left(1-R_{T}^{2}\right)}\right)^{0.5}
$$

with $R_{Y}^{2}$ the coefficient of determination of the statistical model, $R_{T}^{2}$ the correlation between treatment status and the running variable, $N$ the sample size and $P$ the proportion of treated units. 
of this group but nonetheless meaningful. As reported in Figure A.3 in the Appendix, we can detect a change in child employment of at least $20 \%-31 \%$ of the control group's employment rate.

Figure 4: Power (in percent of control group mean outcome) and MDE (at power $=80$ percent) for DDisc Treatment Effects
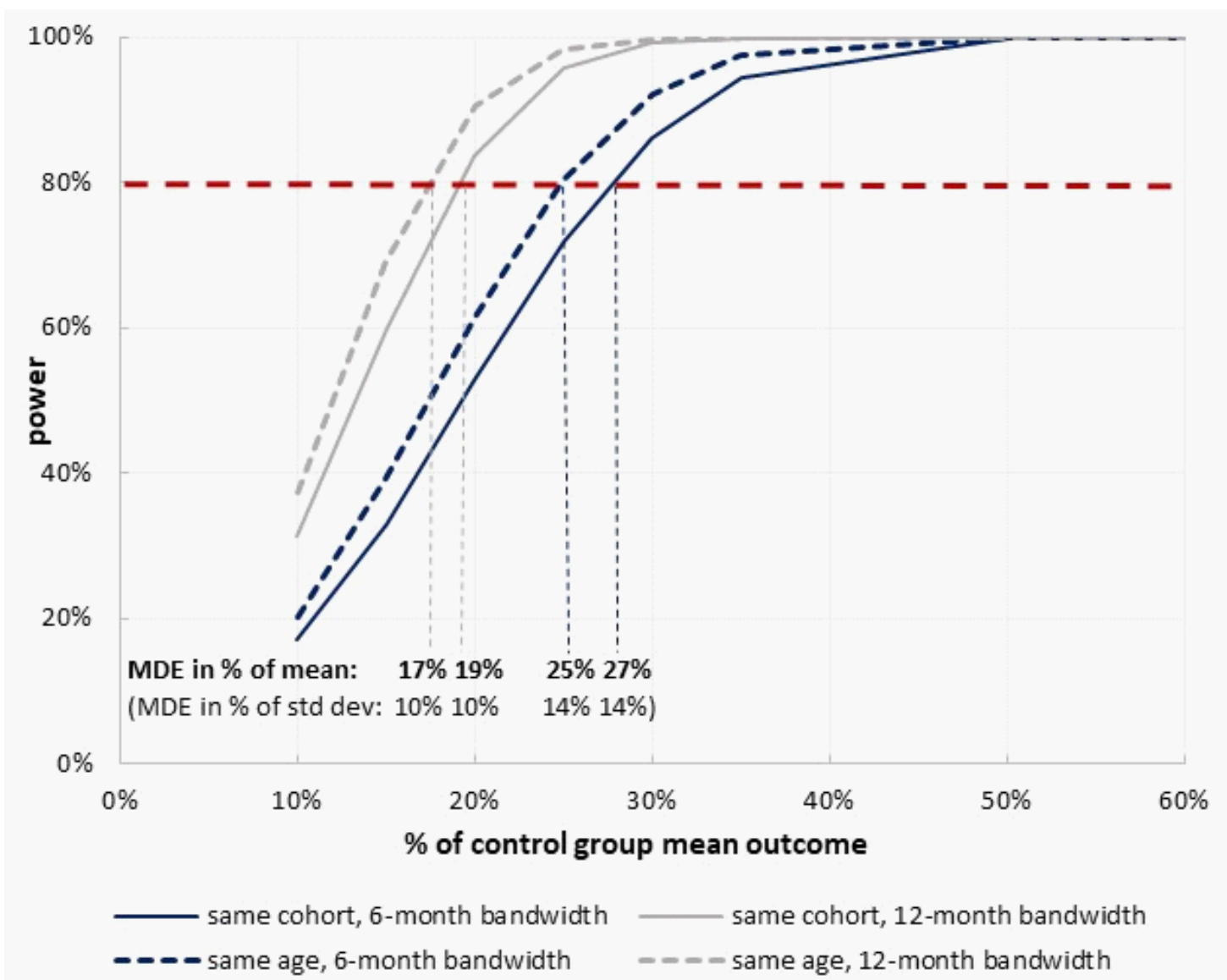

- same cohort, 12-month bandwidth

- - - same age, 12-month bandwidth

The horizontal dashed line cuts the power curves of each model at $80 \%$, hence indicating on the $x$ axis the level of MDE in \% in control group mean outcome at conventional levels (power: $80 \%$, type I: $5 \%$ ). In bracket, below it, is the standardized MDE, i.e. the MDE in \% of the outcome std. deviation.

\subsection{Heterogeneity and Additional Results}

Heterogeneity in the Intensity of Labor Inspections. We check if there is heterogeneity in the effect of the ban. It may possibly due to different degrees of enforcement across regions concerned by various intensities of labor inspections. We simply replicate previous RD and DDisc estimations while interacting the treatment variable with high and low intensity of 
treatment defined as living in a state with above or below average rate of inspection by firm (Almeida and Carnero, 2009). Results are reported in Table 3. Interestingly, child labor seems to decrease in high inspection states. This effect is significant with both the same-cohort and the same-age DDisc designs. This result is confirmed by the sensitivity analysis in Appendix Table A.4. The effect is not significant with the RD when using the quadratic spline function of the running variable. Yet, its magnitude is similar to DDisc estimates and, in Table A.4, we see that all the other RD specifications confirm the magnitude of the effect while most of them point to a significant reduction.

Another interesting result is the decomposition by type of activity. We see that the new minimum age tends to reduce child labor in high inspection states (i.e. where enforcement is the highest) but only in child activities that are most visible (i.e. where compliance is expected to be the highest). This intuitive result is very stable across models and specifications (as can be seen in Appendix Table A.4). It leads to a magnitude between 5.5 and 7 percentage points depending on the estimation, i.e. a reduction between a third and $40 \%$ compared to the visible employment rate of the control group (17\%).

Table 3: Estimates by Inspection Intensity

\begin{tabular}{|c|c|c|c|c|}
\hline Type & & $\begin{array}{c}\text { RD } \\
\text { (Sept. 1999) }\end{array}$ & $\begin{array}{c}\text { DDisc } \\
\text { (same cohort) }\end{array}$ & $\begin{array}{c}\text { DDisc } \\
\text { (same age) }\end{array}$ \\
\hline \multirow[t]{4}{*}{ Overall employment } & Low inspection states & 0.00433 & 0.0176 & $0.0621^{* * *}$ \\
\hline & & $(0.0395)$ & $(0.0251)$ & $(0.0232)$ \\
\hline & High inspection states & -0.0677 & $-0.0802^{* *}$ & $-0.0675^{*}$ \\
\hline & & $(0.0452)$ & $(0.0339)$ & $(0.0354)$ \\
\hline \multirow[t]{4}{*}{ Visible employment } & Low inspection states & -0.00888 & 0.0173 & 0.0328 \\
\hline & & $(0.0300)$ & $(0.0218)$ & $(0.0209)$ \\
\hline & High inspection states & $-0.0629 *$ & $-0.0711^{* *}$ & $-0.0562 *$ \\
\hline & & $(0.0367)$ & $(0.0297)$ & $(0.0317)$ \\
\hline \multirow[t]{4}{*}{ Less visible employment } & Low inspection states & 0.0132 & 0.000284 & $0.0294 * *$ \\
\hline & & $(0.0228)$ & $(0.0139)$ & $(0.0144)$ \\
\hline & High inspection states & -0.00482 & -0.00912 & -0.0113 \\
\hline & & $(0.0250)$ & $(0.0184)$ & $(0.0192)$ \\
\hline
\end{tabular}

Coefficients of treatment effect interacted with low/high inspection rate state. RD: regression discontinuity, DDisc: difference-in-discontinuity, both using 6-month bandwidth. Estimations are based on a quadratic spline function of the running variable (sensitivity analysis is provided in the Appendix). Std errors in brackets. *, **, *** indicate significance levels at $10 \%, 5 \%, 1 \%$. Controls are child gender, ethnicity, household head's age, gender and years of schooling, region, rural, metropolitan area, assets, rate of inspection, home ownership, household size.

Our measure of enforcement is based on a state average of local rates of inspection per firm. Since this is a very broad measure, we have attempted to disaggregate the information a bit more. 
In the left panel of Appendix Table A.5, we replicate estimations using the inspection rates averaged at state $\times$ rural/urban level to obtain more variation. This is especially important as the intensity of inspection tends to be larger in urban areas. In the right panel of the table, we report estimates focusing on urban households. In both cases, results are very much in line with previous findings and point to a significant effect in visible activities when the chances of inspections are high.

Table 4: Estimates: Additional Heterogeneity

\begin{tabular}{lcccc}
\hline Type & All sectors & $\begin{array}{c}\text { Visible activities, } \\
\text { low inspection }\end{array}$ & $\begin{array}{c}\text { Visible activities, } \\
\text { high inspection }\end{array}$ & $\begin{array}{c}\text { Less visible } \\
\text { activities }\end{array}$ \\
\hline Boys (main selection) & 0.0116 & 0.0504 & $-0.0942^{* *}$ & -0.00199 \\
& $(0.0319)$ & $(0.0352)$ & $(0.0440)$ & $(0.0167)$ \\
Girls (main selection) & -0.0216 & -0.00910 & -0.0334 & -0.00681 \\
& $(0.0263)$ & $(0.0244)$ & $(0.0318)$ & $(0.0152)$ \\
Siblings (unbanned, aged 14-16) & -0.0125 & 0.00533 & -0.0152 & -0.0110 \\
& $(0.0621)$ & $(0.0759)$ & $(0.101)$ & $(0.0252)$ \\
\hline
\end{tabular}

Difference-in-discontinuity with 6-month bandwidth and a quadratic spline function of the running variable (sensitivity checks show similar results with alternative specifications - these additional results are available from the authors). Std errors in brackets. *, **, *** indicate significance levels at 10\%,5\%,1\%. Controls are child gender, ethnicity, household head's age, gender and years of schooling, region, rural, metropolitan area, assets, rate of inspection, home ownership, household size.

Additional Results. To refine the picture, a set of heterogeneous effects is reported in Table 4 using the same-cohort DDisc with the 6-month bandwidth (alternative models lead to similar results as what follows). We see that the main effect of the ban, i.e. a decline in visible activities in places with high risk of inspection, is only significant among boys. A larger and more precisely estimated response from boys was expected given their much higher rate of economic activity (27\%) compared to girls (14\%) in 1999, especially in visible activities $(23 \%$ versus $8.5 \%$ ). The magnitude of the effect (9.4 points) relative to the 1999 employment rate of boys in visible activities $(25 \%)$ yields a $38 \%$ reduction, in line with the overall effect found before. Even if not statistically significant, the effect for girls is similar in size (3.3 point drop in visible employment rate relative to a $8.8 \%$ employment rate in the control group, hence a $37.5 \%$ decline).

The rest of Table 4 checks potential compensatory effects by other household members (see also Bharadwaj et al., 2013). We have already commented on the fact that these substitution 
effects within families are not visible in our bandwidth when using the same-age placebo as a counterfactual employment-age pattern. This is confirmed by additional estimations using our selected children's birthdate as forcing variable and the average employment outcome of their older siblings (aged 14-16) as outcome. Finally, it is possible that the law triggers responses regarding other outcomes. Among unreported results, we have checked the potential effect of the new law on school enrollment of children around age 14. We found no significant effect. We also found no particular changes in wage rates.

\section{Conclusion}

This paper provides evidence on the potential effect of a child labor ban exerted by a legal age condition. We exploit the change in the age limit in Brazil, raised from 14 to 16 years old in December 1998. We exploit heterogeneous eligibility among children who turned 14 around the reform date. Local identification in RD and DDisc designs escapes from the usual difficulty of age trend methods like DD with broad comparison groups on each side of the cutoff. We nonetheless find enough power to detect reasonable effects. We find no effect of the ban on child employment overall but a significant and quite substantial reducing effect on children in visible activities in regions where enforcement is potentially high.

Our results tend to confirm previous evidence on the relatively weak effectiveness of minimum age regulation (Edmonds, 2014). Yet we have also established that there is substantial heterogeneity depending on the degree of enforcement. Children in rural areas or in activities that are not easily subject to enforcement measures will probably not be affected by minimum age policies. Other children in visible activities, for instance paid children working with or without a labor card in large firms, may be compelled to withdraw from this type of job by their employers. Yet the effect is diluted and we could only provide suggestive evidence using heterogeneity across broad job types (more or less visible firms) and enforcement degrees (inspection intensity). Further work should attempt to collect more precise data on the degree of potential enforcement, possibly around future change in minimum age laws in other countries. More detailed variation could also allow detecting whether reallocation of children occurs across specific sectors. Finally, better data could say something about the potential impact of a ban on the worst forms of child labor. The literature points to the fact that legal bans may establish new societal norms and provide tools for the legal system to go after firms in case of forced labor (Swinnerton and Rogers, 2008). Legal measures against hazardous did not concern the 14-year old discontinuity exploited in our study, so we could not address this question. More

generally, given the small share of children concerned by this type of work, very detailed data should be collected to identify potential shifts of children out of detrimental sectors. 


\section{References}

[1] Almeida, R. and P. Carneiro (2009): "Enforcement of labor regulation and firm size," Journal of Comparative Economics, 37(1), 28-46

[2] Almeida, R. and P. Carneiro (2012): "Enforcement of Labor Regulation and Informality," American Economic Journal: Applied Economics, 4(3), 64-89

[3] Baland, J.-M. and Robinson, J. A. (2000): "Is child labor inefficient?", Journal of Political Economy, 108 (4), 663-679

[4] Bargain, O. and P. Kwenda (2014): "The Informal Sector Wage Gap: New Evidence Using Quantile Estimations on Panel Data", Economic Development and Cultural Change, $63(1), 117-153$

[5] Basu, K., and Van, P.H. (1998): "The economics of child labor." American Economic Review, 412-427

[6] Basu, K. (2005): "Child labor and the law: Notes on possible pathologies", Economic Letters 87:2, 169-174

[7] Bertrand, M., E. Duflo and S. Mullainathan (2004): "How Much Should We Trust Differences-In-Differences Estimates?", Quarterly Journal of Economics, 119 (1), 249275

[8] Bharadwaj, P., Lakdawala, L. K., and Li, N. (2013): "Perverse Consequences of WellIntentioned Regulation: Evidence from India's Child Labor Ban", NBER Working Paper No. 19602

[9] Bonfim de Almeida, R. and A.L. Kassouf (2016): "The effect of labor inspections on reducing child labor in Brazil", UCW working paper

[10] Boockmann, B. (2010): "The Effect of ILO Minimum Age Conventions on Child Labor" and School Attendance: Evidence From Aggregate and Individual-Level Data", World Development, 38(5), 679-692

[11] Cardoso, F. H. (1997): "Trabalho infantil no Brasil: questões e politicas", in: Conferência de Oslo

[12] Cattaneo, M. D., Titiunik, R., and Vazquez-Bare, G. (2017) : "Power calculations for regression discontinuity designs", Working Paper, University of Michigan

[13] Coslovsky, S.V. (2014): "Flying under the radar? The state and the enforcement of labour laws in Brazil", Oxford Development Studies, 42(2), 190-216

[14] Dessy, S. E. (2000): "A defense of compulsory measures against child labor", Journal of Development Economics, 62 (1), 261-27 
[15] Dessy, S. E. and S. Pallage (2005): "A Theory of the worst form of child labour", Economic Journal, 115, 68-87

[16] Del Vecchio, P. (2005): "Child Labor in Brazil, The Government Commitment", Economic Perspectives, U.S. Department of State, may 2005, volume 10, no.2

[17] Dong, Y. (2015): "Regression Discontinuity Applications with Rounding Errors in the Running Variable.", Journal of Applied Econometrics 30 (3):422-446.

[18] Edmonds, E.V. (2008): "Child Labour", in Schultz, T.P. and Strauss, J. Handbook of Development Economics, Vol. 4. Elsevier, Amsterdam, North Holland

[19] Edmonds, E.V. (2014): "Does minimum age of employment regulation reduce child labor?", IZA World of Labour, 73

[20] Edmonds, E.V. and M. Shrestha (2012): "The Impact of Minimum Age of Employment Regulation on Child Labor and Schooling", IZA Journal of Labor Policy 1(14), 1-28

[21] Ferro, A.R. and A.L. Kassouf (2005): "Efeitos do aumento da idade minima legal no trabalho dos brasileiros de 14 e 15 anos", Revista de Economia e Sociologia Rural, $43(2), 307-329$

[22] Fortin, B., Lacroix, G., Drolet, S. (2004): "Welfare benefits and the duration of welfare spells: evidence from a natural experiment in Canada". Journal of Public Economics $88,1495-1520$

[23] Grembi, V., T. Nannicini and U. Troiano (2016): "Do Fiscal Rules Matter?" (a Differencein-Discontinuities Design), forthcoming in American Economic Journal: Applied Economics

[24] Henley, A., G.R. Arabsheibani and F. Carneiro (2009): "On Defining and Measuring the Informal Sector", World Development, 37, 5, 992-1003

[25] Imbens, G. and T. Lemieux (2008): "Regression Discontinuity Designs: A Guide to Practice", Journal of Econometrics, 142 (2), 615-635

[26] Lee, D.S. and Card, D. (2008): "Regression discontinuity inference with specification error", Journal of Econometrics, 142(2), 655-674

[27] Lee, D. S. and T. Lemieux (2010): "Regression discontinuity designs in economics", Journal of Economic Literature 48 (2), 281-355

[28] Lemieux, T. and K. Milligan (2008): "Incentive effects of social assistance: a regression discontinuity approach", Journal of Econometrics, 142(2), 807-828

[29] Manacorda, M. (2006): "Child Labour and the Labour Supply of Other Household Members: Evidence from 1920 America", American Economic Review, 96, 5, 1788-1801 
[30] Margo, R., and A. Finegan (1996): "Compulsory schooling legislation and school attendance in turn of the century America: A natural experiment approach", Economic Letters 53, 103-110

[31] McCrary, J. (2008): "Manipulation of the running variable in the regression discontinuity design: a density test", Journal of Econometrics, 142(2), 698-714

[32] Moehling, C. (1999): "State child labor laws and the decline of child labor", Explorations in Economic History 36, 72-106

[33] Paes-Sousa, R., L.M Santos and E.S. Miazaki (2011): "Effects of a conditional cash transfer programme on child nutrition in Brazil", Bulletin of the World Health Organization, $89(7), 496-503$

[34] Piza, C. and A. Portela Souza (2016): "The Causal Impacts of Child Labor Law in Brazil: Some Preliminary Findings", World Bank Economic Review, doi: 10.1093/wber/lhw024

[35] Ranjan, P. (1999): "An economic analysis of child labor", Economics Letters, 64 (1), 99-105

[36] Rosati, F.C, M. Manacorda, I. Kovrova, N. Koseleci, S. Lyon (2011): "Understanding the Brazilian success in reducing child labour: empirical evidence and policy lessons", Understanding Children's Work report, ILO

[37] Schochet, P. Z. (2008): "Technical Methods Report: Statistical Power for Regression Discontinuity Designs in Education Evaluations", NCEE 2008-4026, Washington, DC: National Center for Education Evaluation and Regional Assistance.

[38] Silva, P., D. Pessoa and M. Lila (2002): "Análise estatística de dados da PNAD: incorporando a estrutura do plano amostral" (Statistical analysis of data from PNAD: incorporating the sample design), Ciência e Saúde Coletiva, 7(4), 659-670

[39] Somers, M., Zhu, P., Jacob, R. and Bloom, H. (2013): "The validity and precision of the comparative interrupted time series design and the difference-in-difference design in educational evaluation", MDRC working paper in research methodology, NY

[40] Swinnerton, K., and C. Rogers (2008): "A theory of exploitative child labor", Oxford Economic Papers 60, 20-41

[41] UNESCO (2017): "The effect of varying population estimates on the calculation of enrolment rates and out-of-school rates ", UNESCO Institute for Statistics, information paper 36 


\section{A Appendix}

\section{A.1 Alternative Bandwidth}

Table A.1: Treatment and Control Groups with the +/- 6 Months Window

\begin{tabular}{|c|c|c|c|c|}
\hline \multicolumn{5}{|c|}{ Same cohort, different age } \\
\hline \multirow[b]{2}{*}{ Cohort definition } & \multicolumn{4}{|c|}{ PNAD 1998} \\
\hline & $\begin{array}{l}\text { age in } \\
\text { Sept. } 98\end{array}$ & $\begin{array}{l}\text { subject to } \\
\text { old ban }\end{array}$ & $\begin{array}{l}\text { subject to } \\
\text { new ban }\end{array}$ & $\begin{array}{c}\text { allowed to } \\
\text { work }\end{array}$ \\
\hline $\begin{array}{l}\text { Turned } 14 \text { between Dec } 151998 \\
\text { and Mars } 151999\end{array}$ & 13 & yes & - & no \\
\hline $\begin{array}{l}\text { Turned } 14 \text { between Mars } 15 \\
1999 \text { and June } 151999\end{array}$ & 13 & yes & - & no \\
\hline $\begin{array}{l}\text { Turned } 14 \text { between June } 151998 \\
\text { and Sept } 151998\end{array}$ & 14 & no & - & yes \\
\hline $\begin{array}{l}\text { Turned } 14 \text { between Sept } 151998 \\
\text { and Dec } 151998\end{array}$ & 13 & yes & - & no \\
\hline & \multicolumn{4}{|c|}{ PNAD 1999} \\
\hline Cohort definition & $\begin{array}{l}\text { age in } \\
\text { Sept. } 99\end{array}$ & $\begin{array}{l}\text { subject to } \\
\text { old ban }\end{array}$ & $\begin{array}{l}\text { subject to } \\
\text { new ban }\end{array}$ & $\begin{array}{l}\text { allowed to } \\
\text { work }\end{array}$ \\
\hline $\begin{array}{l}\text { Turned } 14 \text { between Dec } 151998 \\
\text { and Mars } 151999\end{array}$ & 14 & - & yes & no \\
\hline $\begin{array}{l}\text { Turned } 14 \text { between Mars } 15 \\
1999 \text { and June } 151999\end{array}$ & 14 & - & yes & no \\
\hline $\begin{array}{l}\text { Turned } 14 \text { between June } 151998 \\
\text { and Sept } 151998\end{array}$ & 15 & - & no & yes \\
\hline $\begin{array}{l}\text { Turned } 14 \text { between Sept } 151998 \\
\text { and Dec } 151998\end{array}$ & 14 & - & no & yes \\
\hline
\end{tabular}

\begin{tabular}{|c|c|c|c|c|}
\hline \multicolumn{5}{|c|}{ Same age, consecutive cohorts } \\
\hline \multirow[b]{2}{*}{ Cohort definition } & \multicolumn{4}{|c|}{ PNAD 1998} \\
\hline & $\begin{array}{l}\text { age in } \\
\text { Sept. } 98\end{array}$ & $\begin{array}{l}\text { subject to } \\
\text { old ban }\end{array}$ & $\begin{array}{l}\text { subject to } \\
\text { new ban }\end{array}$ & $\begin{array}{l}\text { allowed to } \\
\text { work }\end{array}$ \\
\hline $\begin{array}{l}\text { Turned } 14 \text { between Dec } 151997 \\
\text { and Mars } 151998\end{array}$ & 14 & no & - & yes \\
\hline $\begin{array}{l}\text { Turned } 14 \text { between Mars } 15 \\
1998 \text { and June } 151998\end{array}$ & 14 & no & - & yes \\
\hline $\begin{array}{l}\text { Turned } 14 \text { between June } 151997 \\
\text { and Sept } 151997\end{array}$ & 15 & no & - & yes \\
\hline $\begin{array}{l}\text { Turned } 14 \text { between Sept } 151997 \\
\text { and Dec } 151997\end{array}$ & 14 & no & - & yes \\
\hline & \multicolumn{4}{|c|}{ PNAD 1999} \\
\hline Cohort definition & $\begin{array}{l}\text { age in } \\
\text { Sept. } 99\end{array}$ & $\begin{array}{l}\text { subject to } \\
\text { old ban }\end{array}$ & $\begin{array}{l}\text { subject to } \\
\text { new ban }\end{array}$ & $\begin{array}{l}\text { allowed to } \\
\text { work }\end{array}$ \\
\hline $\begin{array}{l}\text { Turned } 14 \text { between Dec } 151998 \\
\text { and Mars } 151999\end{array}$ & 14 & - & yes & no \\
\hline $\begin{array}{l}\text { Turned } 14 \text { between Mars } 15 \\
1999 \text { and June } 151999\end{array}$ & 14 & - & yes & no \\
\hline $\begin{array}{l}\text { Turned } 14 \text { between June } 151998 \\
\text { and Sept } 151998\end{array}$ & 15 & - & no & yes \\
\hline $\begin{array}{l}\text { Turned } 14 \text { between Sept } 151998 \\
\text { and Dec } 151998\end{array}$ & 14 & - & no & yes \\
\hline
\end{tabular}

Treatment "banned from work due to minimal age condition" indicated in grey. It is due to old ban for only $3 / 4$ of the 1998 observations and to new ban for the first halfcohort in 1999.

Treatment "banned from work due to minimal age condition" indicated in grey. It is due to the new ban for the first half-cohort in 1999. 


\section{A.2 Comparing Sub-Cohorts around the Cutoff}

Table A.2 shows descriptive statistics for our 1999 selection with either the 6 -month or 12-month bandwiths around the cutoff. The main observation is that characteristics of the subcohorts on either side of the birthdate threshold are rarely statistically different. Whatever the bandwidth, a F-test cannot reject the null that the two sub-cohorts have the same characteristics. Yet, as expected, the broader bandwith shows more differences between the two subgroups than the narrow bandwith does.

Table A.2: Descriptive Statistics around the Cutoff (year 1999)

\begin{tabular}{|c|c|c|c|c|c|c|c|c|}
\hline \multirow[b]{3}{*}{ Region Norte } & \multicolumn{4}{|c|}{ 6-month bandwidth } & \multicolumn{4}{|c|}{ 12-month bandwidth } \\
\hline & \multirow{2}{*}{$\begin{array}{c}\text { birth }< \\
\text { midDec }\end{array}$} & \multirow{2}{*}{$\begin{array}{c}\begin{array}{c}\text { birth }> \\
\text { mid Dec }\end{array} \\
0.07\end{array}$} & \multicolumn{2}{|c|}{ Diff. } & \multicolumn{2}{|c|}{$\begin{array}{l}\text { birth }<\text { birth }> \\
\text { midDec mid Dec }\end{array}$} & \multicolumn{2}{|c|}{ Diff. } \\
\hline & & & -0.02 & $* *$ & 0.09 & 0.07 & -0.02 & $* * *$ \\
\hline Region Nordeste & 0.32 & 0.35 & 0.03 & $*$ & 0.33 & 0.36 & 0.03 & ** \\
\hline Region Sudeste & 0.33 & 0.32 & -0.01 & & 0.33 & 0.32 & -0.01 & \\
\hline Region Sul & 0.16 & 0.17 & 0.01 & & 0.16 & 0.16 & 0.00 & \\
\hline Rural & 0.21 & 0.21 & 0.00 & & 0.21 & 0.21 & 0.00 & \\
\hline Metropolitan area & 0.37 & 0.39 & 0.02 & & 0.36 & 0.38 & 0.02 & \\
\hline Ethnicity (branca) & 0.49 & 0.52 & 0.03 & & 0.48 & 0.48 & 0.00 & \\
\hline Ethnicity (parda) & 0.46 & 0.44 & -0.02 & & 0.46 & 0.48 & 0.02 & \\
\hline Head: education & 5.30 & 5.41 & 0.11 & & 5.16 & 5.31 & 0.15 & \\
\hline Head: mother & 0.22 & 0.20 & -0.02 & & 0.22 & 0.20 & -0.02 & $*$ \\
\hline Head: age & 43.69 & 43.59 & -0.1 & & 43.70 & 43.54 & -0.16 & \\
\hline Assets & 5.01 & 5.06 & 0.05 & & 4.96 & 5.02 & 0.06 & \\
\hline Inspection intensity & 4.53 & 4.43 & -0.1 & & 4.42 & 4.34 & -0.08 & \\
\hline Home owner & 0.75 & 0.73 & -0.02 & & 0.74 & 0.73 & -0.01 & \\
\hline Household size & 5.45 & 5.37 & -0.08 & & 5.44 & 5.35 & -0.09 & $*$ \\
\hline
\end{tabular}




\section{A.3 Errors and Manipulation of Birthdate}

Birth registration is compulsory in Brazil. Without birth certificates children cannot be vaccinated or enrolled in school, and unregistered adult cannot obtain a worker's card. This should limit measurement error. It also establishes that firms are in principle aware of the precise age of their workforce. Yet, while the vast majority of children have a birth certificate, due to increased access to birth registration (UNICEF, 2017), a non-negligible fraction of children had no birth certificate in rural areas. ${ }^{19}$ In the text, we provide sensitivity checks whereby we exclude the rural population. Here, we also verify that the birthdate density in our selection shows no discontinuous jump just before the reform date, which would indicate age manipulation in the PNAD data (McCrary, 2008). If we misclassify children due to misreporting of their exact age, we should observe a discontinuity in birthdate density around the cutoff. Figure A.1 shows that in September 1999, with both 6-month and 12-month bandwidths (upper and lower left panels respectively), we find no significant difference in birthdate density. Formal tests cannot reject the null hypothesis of equal density. Note that the slight decrease on the left of the cutoff is actually opposite to what we would expect in case of misdeclaration to avoid the new ban (i.e. more children to the left of the cutoff). For a comparison, we also provide similar graphs for 1998 (right panel), using the same-age (previous cohort) children. The distribution of birthdates is relatively uniform across time around mid-December, as was the case for 1999.

\footnotetext{
${ }^{19}$ This would concern around $20 \%$ of children in the late 1990s according to IBGE, especially among indigenous populations. According to Paes-Souza et al. (2011), the lack of certificate is an indicator of extreme poverty and of residence in an isolated area.
} 
Figure A.1: "McCrary Density Checks around the Cutoff
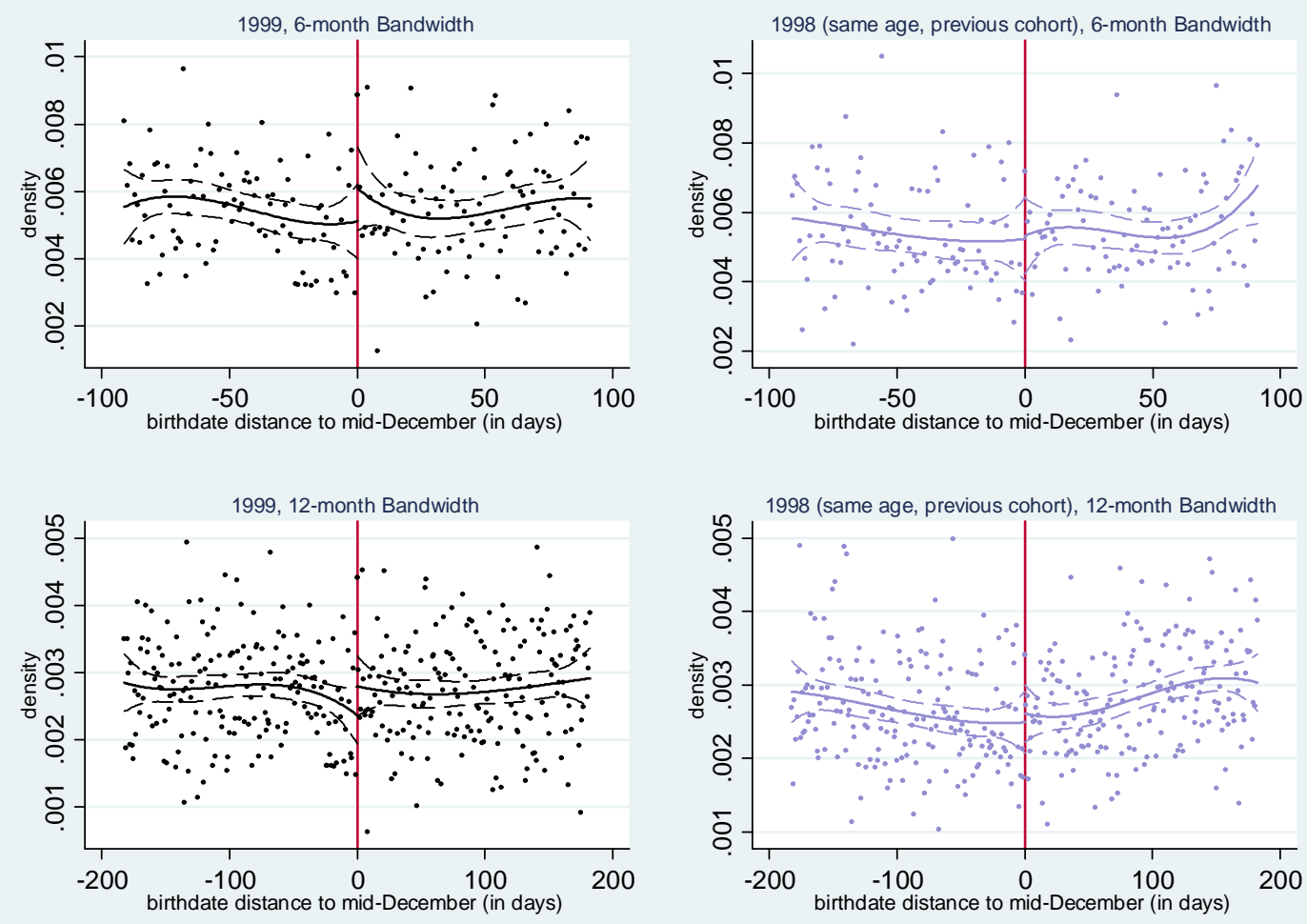


\section{A.4 Sensitivity Analysis and Additional Results}

Figure A.2: RD and DDisc (same-age): Graphical Evidence (Total Employment, 6-months Bandwidth)

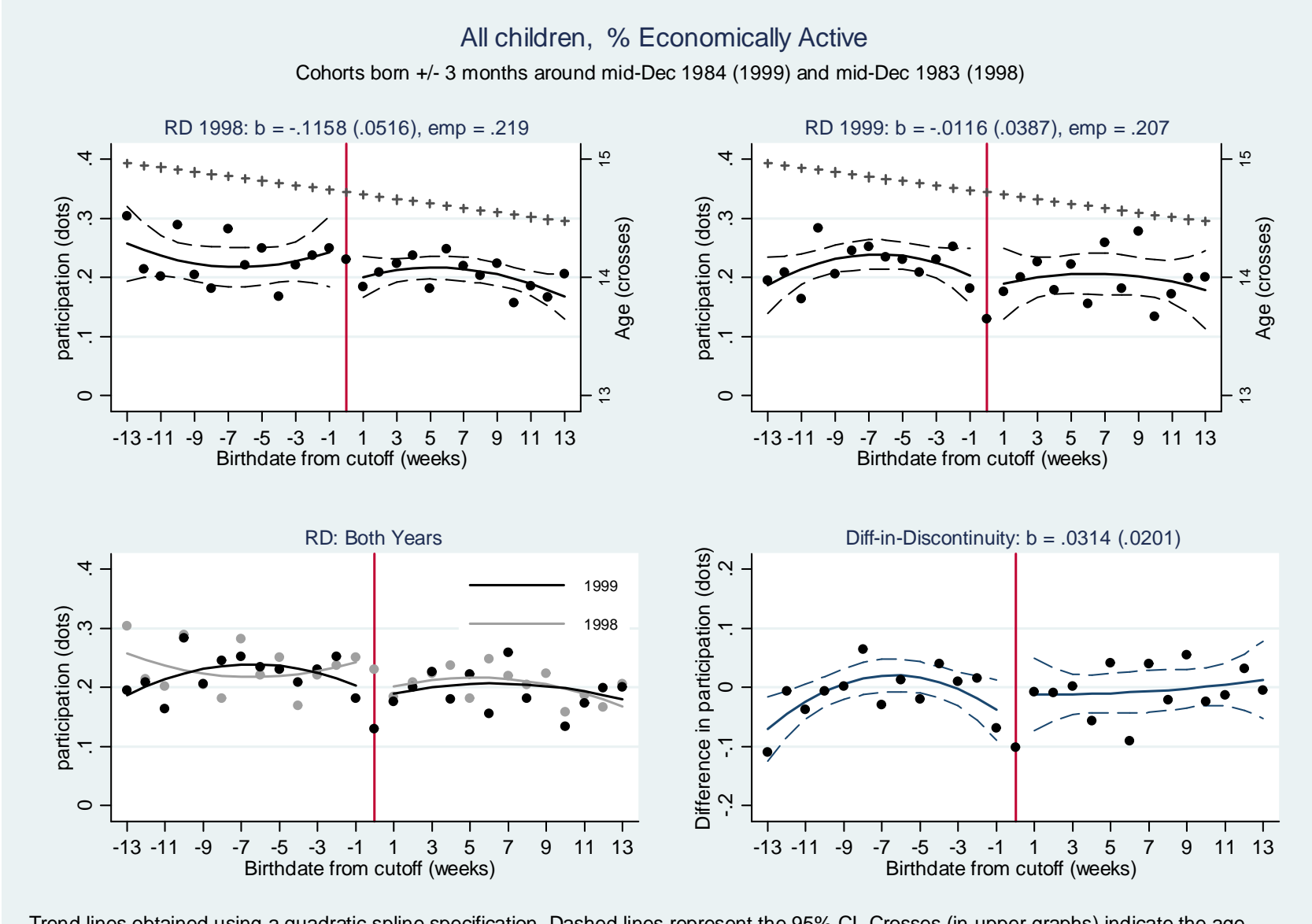

Trend lines obtained using a quadratic spline specification. Dashed lines represent the $95 \% \mathrm{Cl}$. Crosses (in upper graphs) indicate the age 
Figure A.3: Power (in percent of control group mean outcome) and MDE (at power $=80$ percent) for DDisc Treatment Effects: Visible Sector

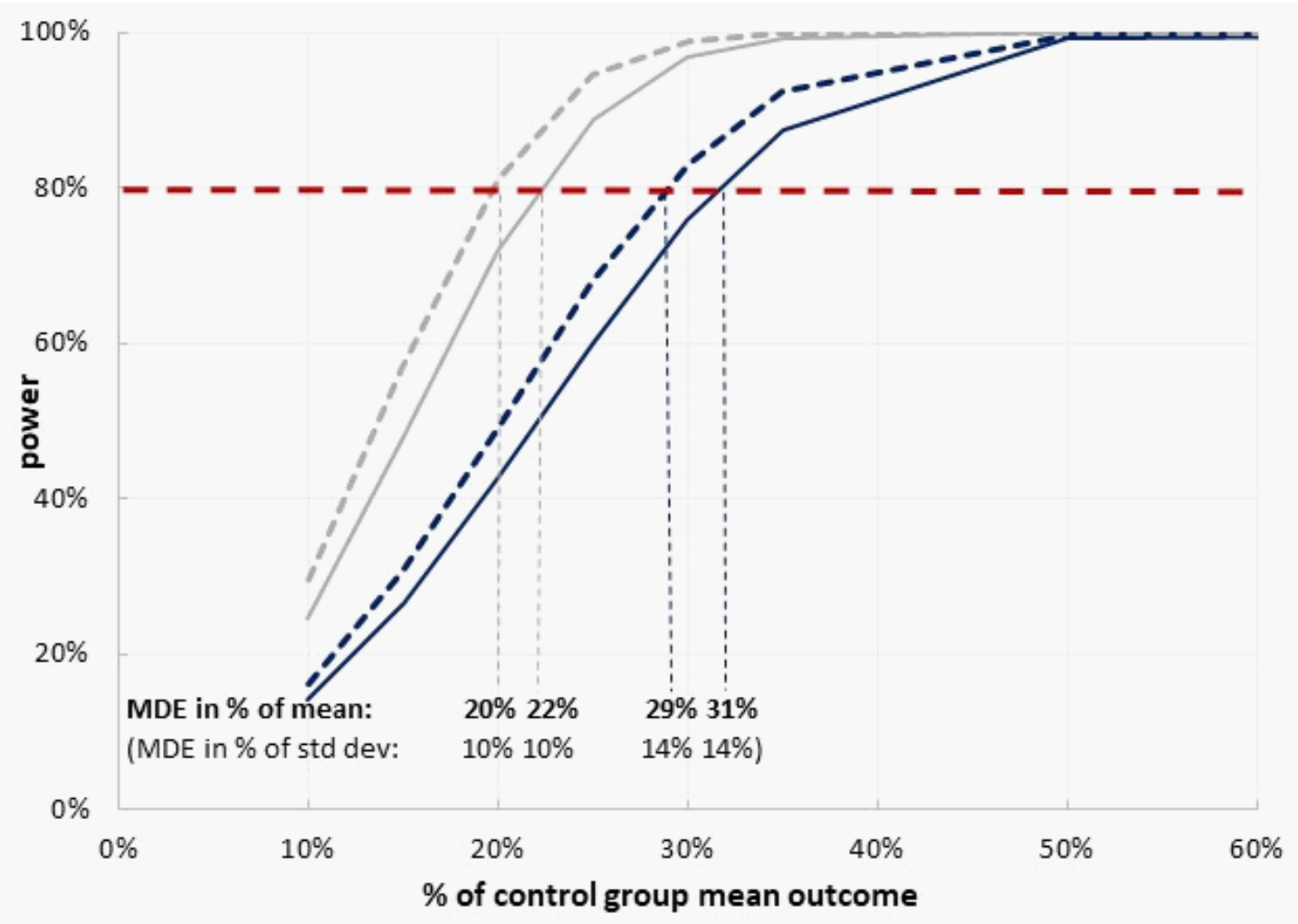

$$
\begin{aligned}
& \text { — same cohort, } 6 \text {-month bandwidth } \quad \text { same cohort, } 12 \text {-month bandwidth } \\
& \text { - same age, } 6 \text {-month bandwidth }
\end{aligned}
$$

The horizontal dashed line cuts the power curves of each model at $80 \%$, hence indicating on the $x$ axis the level of MDE in \% in control group mean outcome at conventional levels (power: $80 \%$, type I: $5 \%$ ). In bracket, below it, is the standardized MDE, i.e. the MDE in \% of the outcome std. deviation. 


\section{Table A.3: Estimates based on Discontinuity in Treatment: Sensitivity Analysis'}

\begin{tabular}{|c|c|c|c|c|c|c|c|c|c|c|c|c|c|}
\hline \multirow[b]{2}{*}{ Type } & \multirow[b]{2}{*}{ Bandwidth } & \multicolumn{4}{|c|}{ RD (Sept. 1999) } & \multicolumn{4}{|c|}{ DDisc (same cohort) } & \multicolumn{4}{|c|}{ DDisc (same age) } \\
\hline & & linear & quadratic & cubic & $\begin{array}{l}\text { linear } \\
\text { spline }\end{array}$ & linear & quadratic & cubic & $\begin{array}{l}\text { linear } \\
\text { spline }\end{array}$ & linear & quadratic & cubic & $\begin{array}{l}\text { linear } \\
\text { spline }\end{array}$ \\
\hline \multirow[t]{2}{*}{ Overall employment } & 6 months & -0.0119 & -0.0120 & -0.00632 & -0.0119 & -0.00620 & -0.00623 & -0.00630 & -0.00625 & 0.0315 & 0.0315 & 0.0312 & 0.0316 \\
\hline & & $(0.0289)$ & $(0.0290)$ & $(0.0392)$ & $(0.0288)$ & $(0.0220)$ & $(0.0220)$ & $(0.0220)$ & $(0.0220)$ & $(0.0202)$ & $(0.0202)$ & $(0.0201)$ & $(0.0202)$ \\
\hline \multirow[t]{2}{*}{ Overall employment } & 12 months & 0.0194 & 0.0195 & -0.0270 & 0.0195 & 0.000575 & 0.000538 & 0.000566 & 0.000545 & $0.0300^{* *}$ & $0.0300^{* *}$ & $0.0299 * *$ & $0.0300 * *$ \\
\hline & & $(0.0214)$ & $(0.0212)$ & $(0.0275)$ & $(0.0211)$ & $(0.0151)$ & $(0.0151)$ & $(0.0151)$ & $(0.0151)$ & $(0.0141)$ & $(0.0141)$ & $(0.0140)$ & $(0.0141)$ \\
\hline \multirow[t]{2}{*}{ Visible employment } & 6 months & -0.0221 & -0.0221 & -0.0198 & -0.0221 & -0.00412 & -0.00414 & -0.00414 & -0.00416 & 0.0120 & 0.0120 & 0.0118 & 0.0120 \\
\hline & & $(0.0226)$ & $(0.0228)$ & $(0.0295)$ & $(0.0227)$ & $(0.0187)$ & $(0.0187)$ & $(0.0187)$ & $(0.0187)$ & $(0.0184)$ & $(0.0184)$ & $(0.0183)$ & $(0.0184)$ \\
\hline \multirow[t]{2}{*}{ Less visible employment } & 6 months & 0.0101 & 0.0101 & 0.0135 & 0.0102 & -0.00208 & -0.00209 & -0.00216 & -0.00209 & 0.0196 & 0.0196 & 0.0195 & 0.0196 \\
\hline & & $(0.0159)$ & $(0.0159)$ & $(0.0207)$ & $(0.0158)$ & $(0.0118)$ & $(0.0118)$ & $(0.0118)$ & $(0.0118)$ & $(0.0124)$ & $(0.0124)$ & $(0.0124)$ & $(0.0124)$ \\
\hline \multirow[t]{2}{*}{ Overall empl., urban } & 6 months & -0.00781 & -0.00735 & 0.0102 & -0.00699 & -0.00353 & -0.00370 & -0.00370 & -0.00373 & 0.0284 & 0.0284 & 0.0285 & 0.0285 \\
\hline & & $(0.0339)$ & $(0.0333)$ & $(0.0462)$ & $(0.0323)$ & $(0.0220)$ & $(0.0220)$ & $(0.0220)$ & $(0.0220)$ & $(0.0226)$ & $(0.0226)$ & $(0.0226)$ & $(0.0226)$ \\
\hline \multirow[t]{2}{*}{ Visible empl., urban } & 6 months & -0.0151 & -0.0149 & -0.000439 & -0.0146 & -0.00442 & -0.00452 & -0.00445 & -0.00455 & 0.00491 & 0.00495 & 0.00495 & 0.00500 \\
\hline & & $(0.0268)$ & $(0.0265)$ & $(0.0362)$ & $(0.0259)$ & $(0.0177)$ & $(0.0176)$ & $(0.0176)$ & $(0.0176)$ & $(0.0190)$ & $(0.0189)$ & $(0.0190)$ & $(0.0189)$ \\
\hline \multirow[t]{2}{*}{ Less visible empl., urban } & 6 months & 0.00726 & 0.00754 & 0.0107 & 0.00760 & 0.000895 & 0.000819 & 0.000753 & 0.000820 & $0.0235^{*}$ & $0.0235^{*}$ & $0.0235^{*}$ & $0.0235^{*}$ \\
\hline & & $(0.0185)$ & $(0.0183)$ & $(0.0234)$ & $(0.0182)$ & $(0.0129)$ & $(0.0129)$ & $(0.0129)$ & $(0.0129)$ & $(0.0140)$ & $(0.0140)$ & $(0.0140)$ & $(0.0140)$ \\
\hline
\end{tabular}


Table A.4: Estimates by Inspection Intensity: Sensitivity Analysis

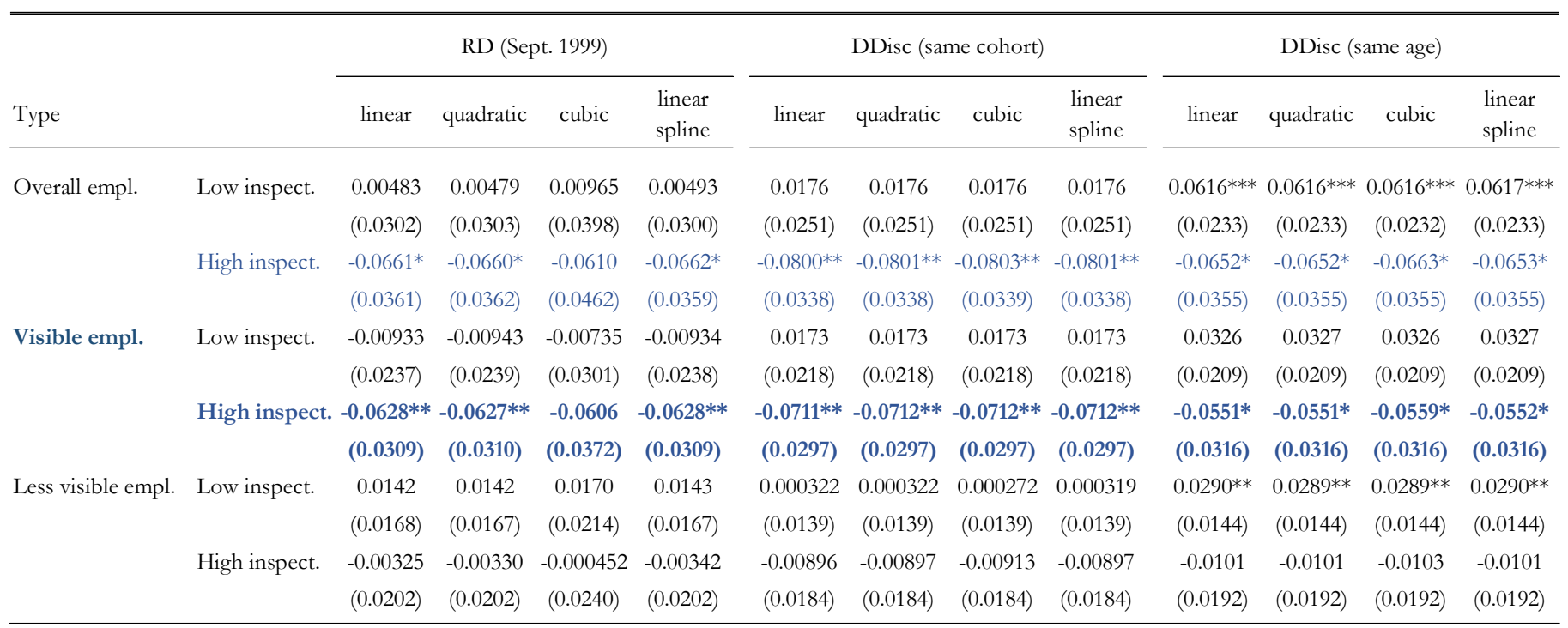

Coefficients of treatment effect interacted with low/high inspection rate state. RD: regression discontinuity, DDisc: difference-in-discontinuity, both using 6-month bandwidth. Estimations are based on alternative smooth functions of the running variable (linear, quadratic, cubic, linear spline). Std errors in brackets. *, **, *** indicate significance levels at $10 \%, 5 \%, 1 \%$. Controls are child gender, ethnicity, household head's age, gender and years of schooling, region, rural, metropolitan area, assets, rate of inspection, home ownership, household size.

\section{Table A.5: Estimates by Inspection Intensity: More Geographical Variation}

\begin{tabular}{|c|c|c|c|c|c|c|c|}
\hline \multirow[b]{2}{*}{ Type } & & \multicolumn{3}{|c|}{ More disaggregated inspection rate } & \multicolumn{3}{|c|}{ Urban sample } \\
\hline & & $\begin{array}{c}\text { RD } \\
\text { (Sept. 1999) }\end{array}$ & $\begin{array}{c}\text { DDisc } \\
\text { (same cohort) }\end{array}$ & $\begin{array}{c}\text { DDisc } \\
\text { (same age) }\end{array}$ & $\begin{array}{c}\text { RD } \\
\text { (Sept. } \\
1999)\end{array}$ & $\begin{array}{l}\text { DDisc } \\
\text { (same } \\
\text { cohort) }\end{array}$ & $\begin{array}{c}\text { DDisc } \\
\text { (same age) }\end{array}$ \\
\hline \multirow[t]{4}{*}{ Overall employment } & Low inspection states & 0.00972 & 0.0113 & $0.0766^{* * *}$ & 0.0275 & 0.0183 & $0.0577^{* *}$ \\
\hline & & $(0.0405)$ & $(0.0279)$ & $(0.0250)$ & $(0.0420)$ & $(0.0243)$ & $(0.0265)$ \\
\hline & High inspection states & -0.0413 & -0.0326 & -0.0366 & -0.0521 & $-0.0626^{*}$ & -0.0516 \\
\hline & & $(0.0419)$ & $(0.0257)$ & $(0.0275)$ & $(0.0500)$ & $(0.0335)$ & $(0.0337)$ \\
\hline \multirow[t]{4}{*}{ Visible employment } & Low inspection states & 0.00318 & 0.0200 & $0.0500^{* *}$ & -0.00888 & 0.0151 & 0.0221 \\
\hline & & $(0.0308)$ & $(0.0250)$ & $(0.0227)$ & $(0.0329)$ & $(0.0201)$ & $(0.0227)$ \\
\hline & High inspection states & $-0.0569 * *$ & $-0.0406 *$ & $-0.0458^{*}$ & $-0.0555^{*}$ & $-0.0578 * *$ & -0.0416 \\
\hline & & $(0.0267)$ & $(0.0219)$ & $(0.0246)$ & $(0.0310)$ & $(0.0273)$ & $(0.0276)$ \\
\hline \multirow[t]{4}{*}{ Less visible employment } & Low inspection states & 0.00655 & -0.00866 & 0.0266 & 0.0129 & 0.00317 & $0.0356^{* *}$ \\
\hline & & $(0.0246)$ & $(0.0156)$ & $(0.0164)$ & $(0.0254)$ & $(0.0155)$ & $(0.0162)$ \\
\hline & High inspection states & 0.0136 & 0.00800 & 0.00923 & -0.0116 & -0.00480 & -0.00995 \\
\hline & & $(0.0217)$ & $(0.0139)$ & $(0.0145)$ & $(0.0284)$ & $(0.0192)$ & $(0.0202)$ \\
\hline
\end{tabular}

Coefficients of treatment effect interacted with low/high inspection rate state. RD: regression discontinuity, DDisc: difference-in-discontinuity, both using 6-month bandwidth. Estimations are based on a quadratic spline function of the running variable (sensitivity analysis is provided in the Appendix). Std errors in brackets. *, $* *, * * *$ indicate significance levels at $10 \%, 5 \%, 1 \%$. Controls are child gender, ethnicity, household head's age, gender and years of schooling, region, rural, metropolitan area, assets, rate of inspection, home ownership, household size. More disaggregated inspection intensity is the rate at state $\mathrm{x}$ rural/urban level. 